\title{
Estimating marine aerosol particle volume and number from Maritime Aerosol Network data
}

\author{
A. M. Sayer ${ }^{1,2}$, A. Smirnov ${ }^{2,3}$, N. C. Hsu ${ }^{2}$, L. A. Munchak ${ }^{2,4}$, and B. N. Holben ${ }^{2}$ \\ ${ }^{1}$ Goddard Earth Sciences Technology And Research (GESTAR), Universities Space Research Association (USRA), \\ Columbia, Maryland, USA \\ ${ }^{2}$ NASA Goddard Space Flight Center, Greenbelt, Maryland, USA \\ ${ }^{3}$ Sigma Space Corporation, Lanham, Maryland, USA \\ ${ }^{4}$ Science Systems Applications Inc., Lanham, Maryland, USA
}

Correspondence to: A. M. Sayer (andrew.sayer@nasa.gov)

Received: 21 May 2012 - Published in Atmos. Chem. Phys. Discuss.: 12 June 2012

Revised: 27 August 2012 - Accepted: 13 September 2012 - Published: 28 September 2012

\begin{abstract}
As well as spectral aerosol optical depth (AOD), aerosol composition and concentration (number, volume, or mass) are of interest for a variety of applications. However, remote sensing of these quantities is more difficult than for AOD, as it is more sensitive to assumptions relating to aerosol composition. This study uses spectral AOD measured on Maritime Aerosol Network (MAN) cruises, with the additional constraint of a microphysical model for unpolluted maritime aerosol based on analysis of Aerosol Robotic Network (AERONET) inversions, to estimate these quantities over open ocean. When the MAN data are subset to those likely to be comprised of maritime aerosol, number and volume concentrations obtained are physically reasonable. Attempts to estimate surface concentration from columnar abundance, however, are shown to be limited by uncertainties in vertical distribution. Columnar AOD at $550 \mathrm{~nm}$ and aerosol number for unpolluted maritime cases are also compared with Moderate Resolution Imaging Spectroradiometer (MODIS) data, for both the present Collection 5.1 and forthcoming Collection 6. MODIS provides a best-fitting retrieval solution, as well as the average for several different solutions, with different aerosol microphysical models. The "average solution" MODIS dataset agrees more closely with MAN than the "best solution" dataset. Terra tends to retrieve lower aerosol number than MAN, and Aqua higher, linked with differences in the aerosol models commonly chosen. Collection 6 AOD is likely to agree more closely with MAN over open ocean than Collection 5.1. In situations where spectral AOD is measured accurately, and aerosol microphysical properties
\end{abstract}

are reasonably well-constrained, estimates of aerosol number and volume using MAN or similar data would provide for a greater variety of potential comparisons with aerosol properties derived from satellite or chemistry transport model data. However, without accurate AOD data and prior knowledge of microphysical properties, such attempts are fraught with high uncertainties.

\section{Introduction}

Columnar aerosol optical depth (AOD) has been mapped on a near-global basis for several decades from satellite measurements with varying degrees of accuracy (e.g., Stowe et al., 1997; Hsu et al., 1999; Higurashi et al., 2000; Torres et al., 2002; Mishchenko et al., 2007; Remer et al., 2008; Thomas et al., 2009; Kahn et al., 2010; Sayer et al., 2012a). There is a similar wealth of ground-based aerosol observations from techniques such as sun photometry, lidar, or multifilter rotating shadowband radiometers, with records approaching two decades at some locations (e.g., Holben et al., 1998; Michalsky et al., 2001; Campbell et al., 2002). The AOD represents the vertically-integrated extinction of light by aerosol particles,

$\tau_{\lambda}=\int_{0}^{\infty} \beta_{\lambda}(z) \mathrm{d} z$ 
where $\tau_{\lambda}$ is the AOD at wavelength $\lambda$, and $\beta_{\lambda}$ the aerosol extinction (sum of scattering and absorption) at that wavelength and altitude $z$, and as such is related to the aerosol mass loading of the atmosphere. To illustrate the role of aerosol composition more explicitly, for a given altitude,

$\beta_{\lambda}=\int_{0}^{\infty} \pi r^{2} Q_{\text {ext }}(r, \lambda, m) N(r) \mathrm{d} r$

where $Q_{\text {ext }}$ is the extinction efficiency factor, dependent on particle radius $(r)$, wavelength, and complex refractive index $(m)$, and $N(r)$ is an arbitrary function describing the number of aerosol particles of a given size. Both size distribution and refractive index are functions of aerosol composition and state of hydration (discussed in more detail later).

The spectral behaviour of AOD, frequently referred to in the context of the Ångström parameter $\alpha$, where

$\alpha=-\frac{\mathrm{d} \ln \left(\tau_{\lambda}\right)}{\mathrm{d} \ln (\lambda)}$,

is often evaluated across the visible region of the solar spectrum and used as a first-order indication of aerosol type (Eck et al., 1999; Dubovik et al., 2002). However, $\alpha$ is not a unique identifier of a particular aerosol composition, so additional constraints such as microphysical aerosol particle models are necessary to infer physical aerosol amount from AOD. Further, particularly in low-AOD regimes, satellite and groundbased estimates of $\alpha$ can suffer from significant uncertainty (Wagner and Silva, 2008). These factors mean that estimating aerosol number or volume from remotely-sensed AOD is, at present, not straightforward. Sensitivity studies (e.g. González Jorge and Ogren, 1996, Mishchenko et al., 1997a, Hasekamp and Landgraf, 2005) have previously outlined some of these difficulties. Remote determination of aerosol number or volume/mass rather than solely AOD is of interest to estimate, for example, the deposition flux of mineral dust aerosols (Kaufman et al., 2005), near-surface particulate matter concentration in urban areas (Hoff and Christopher, 2009), aerosol radiative forcing (Quaas et al., 2008; Yu et al., 2012), or the available number of particles which can act as cloud condensation nuclei (CCN) and influence cloud development (Jefferson, 2010).

Recently, Sayer et al. (2012b) analysed size distribution inversions from a selection of Aerosol Robotic Network (AERONET) coastal and island sites (Holben et al., 1998; Dubovik and King, 2000), and arrived at a microphysical model of pure maritime aerosol as a combination of two lognormally-distributed components. The properties of maritime aerosol were found to be similar over the range of sites, such that the observed AERONET AOD record at these sites could be well-reproduced by varying only two free parameters, namely the fine-mode and coarse-mode aerosol volume. The Maritime Aerosol Network (MAN) provides shipbased observations of spectral AOD over the ocean (Smirnov et al., 2009, 2011), with typically four (sometimes five) spectral channels in any individual measurement. Thus, the model can be used to infer columnar aerosol number and volume of maritime aerosol from the MAN AOD measurements (size distribution inversions as performed at the AERONET land sites are not possible from the hand-held measurements collected on MAN cruises). The aim of this study is to perform such an exercise.

This is first a test of whether the model of Sayer et al. (2012b) is able to produce physically-reasonable values of aerosol concentration. It also allows a comparison of derived aerosol number with the (unvalidated) aerosol columnar number concentration estimates provided in the Moderate Resolution Imaging Spectroradiometer (MODIS) satellite aerosol product (Remer et al., 2005, 2008). These open up further scope for evaluation of the aerosol parametrisation of chemistry transport models (CTMs) through comparisons with aerosol number or volume as well as AOD. This is important because CTM aerosol fields are diverse, and it is possible for the CTM to produce the right AOD but with the wrong aerosol composition (e.g., Kinne et al., 2006; Textor et al., 2006). Uncertainties in the MAN-derived estimates are also discussed.

The notation adopted in this work follows that of Sayer et al. (2012b), in which various identities and derivations are presented. A summary of relevant notation is presented here. The aerosol number size distribution written in differential form $\mathrm{d} N(r) / \mathrm{d} \ln (r)$ describes the number of aerosol particles with radius in the infinitesimal size range $r \pm \mathrm{d} \ln (r)$; for spherical particles, this is related to the volume size distribution $\mathrm{d} V(r) / \mathrm{d} \ln (r)$ by

$\frac{\mathrm{d} V(r)}{\mathrm{d} \ln (r)}=\frac{4 \pi r^{3}}{3} \frac{\mathrm{d} N(r)}{\mathrm{d} \ln (r)}$.

In this work and many others (Sayer et al., 2012b, and references therein) aerosol particle size distributions are represented as a sum of $n_{\mathrm{c}}$ lognormally-distributed components,

$\frac{\mathrm{d} N(r)}{\mathrm{d} \ln (r)}=\sum_{i=1}^{n_{\mathrm{c}}} \frac{C_{\mathrm{n}, i}}{\sqrt{2 \pi} \sigma_{i}} e^{-\frac{1}{2}\left(\frac{\ln (r)-\ln \left(r_{\mathrm{n}, i}\right)}{\sigma_{i}}\right)^{2}}$,

where $r_{\mathrm{n}}$ and $\sigma$ are the mode's modal (also median and geometric mean) radius and geometric standard deviation, respectively, and $C_{\mathrm{n}}$ the total number of aerosol particles in the mode. The equivalent aerosol volume distribution is given by the same expression, except substituting $r_{\mathrm{n}}$ with the volume median radius $r_{\mathrm{v}}$, and $C_{\mathrm{n}}$ with the total aerosol volume $C_{\mathrm{v}}$. The relationships between these quantities for a lognormal component (Sayer et al., 2012b) are

$r_{\mathrm{v}}=r_{\mathrm{n}} e^{3 \sigma^{2}}$

and

$C_{\mathrm{v}}=\frac{4 \pi}{3} r_{\mathrm{n}}^{3} e^{4.5 \sigma^{2}} C_{\mathrm{n}}$, 
Table 1. Aerosol microphysical model parameters. $r_{\mathrm{n}}$ is the modal radius, $\sigma$ the geometric standard deviation, $m$ the complex refractive index at $550 \mathrm{~nm}$, and $C_{\mathrm{n}} / C_{\mathrm{v}}$ the ratio of aerosol particle number to volume. The extinction coefficient at $550 \mathrm{~nm}$ is denoted $\beta_{550}$, given both per $\mu \mathrm{m}^{3}$ and per particle.

\begin{tabular}{|c|c|c|c|c|c|c|c|}
\hline \multirow[t]{2}{*}{ Reference } & \multirow[t]{2}{*}{ Aerosol model } & \multicolumn{3}{|c|}{ Parameters } & \multirow{2}{*}{$\begin{array}{l}\beta_{550}, \\
\mu \mathrm{m}^{-3}\end{array}$} & \multirow{2}{*}{$\begin{array}{l}\beta_{550}, \text { per } \\
\text { particle, } \times 10^{-14}\end{array}$} & \multirow{2}{*}{$\begin{array}{l}C_{\mathrm{n}} / C_{\mathrm{V}}, \\
\mu \mathrm{m}^{-3}\end{array}$} \\
\hline & & $r_{\mathrm{n}}, \mu \mathrm{m}$ & $\sigma$ & $m$ & & & \\
\hline \multirow[t]{2}{*}{ Sayer et al. (2012b) } & Marine, fine mode & 0.0742 & 0.50 & $1.415-0.002 i$ & 4.27 & 2.25 & 190 \\
\hline & Marine, coarse mode & 0.547 & 0.72 & $1.363-3 \times 10^{-9} i$ & 0.90 & 637 & 0.14 \\
\hline \multirow[t]{4}{*}{ Sayer et al. (2012a) } & Marine/continental, fine mode & 0.106 & 0.44 & $1.43-0.0075 i$ & 5.53 & 6.65 & 83 \\
\hline & Marine/continental, coarse mode & 0.774 & 0.65 & $1.43-0.0075 i$ & 0.78 & 1010 & 0.08 \\
\hline & Marine/dust, fine mode & 0.0632 & 0.43 & $1.47-0.002 i$ & 3.36 & 0.82 & 412 \\
\hline & Marine/dust, coarse mode & 0.993 & 0.49 & $1.47-0.002 i$ & 0.96 & 1060 & 0.08 \\
\hline \multirow[t]{9}{*}{ Remer et al. (2009) } & MODIS \#1 (fine mode) & 0.07 & 0.40 & $1.45-0.0035 i$ & 3.21 & 0.95 & 339 \\
\hline & MODIS \#2 (fine mode) & 0.06 & 0.60 & $1.45-0.0035 i$ & 5.17 & 2.36 & 219 \\
\hline & MODIS \#3 (fine mode) & 0.08 & 0.60 & $1.40-0.002 i$ & 5.09 & 5.51 & 92 \\
\hline & MODIS \#4 (fine mode) & 0.1 & 0.60 & $1.40-0.002 i$ & 5.36 & 11.4 & 47 \\
\hline & MODIS \#5 (coarse mode) & 0.4 & 0.60 & $1.35-0.001 i$ & 2.06 & 278 & 0.74 \\
\hline & MODIS \#6 (coarse mode) & 0.6 & 0.60 & $1.35-0.001 i$ & 1.26 & 576 & 0.22 \\
\hline & MODIS \#7 (coarse mode) & 0.8 & 0.60 & $1.35-0.001 i$ & 0.90 & 973 & 0.09 \\
\hline & MODIS \#8 (coarse mode) & 0.6 & 0.60 & $1.53-0.001 i$ & 1.22 & 557 & 0.22 \\
\hline & MODIS \#9 (coarse mode) & 0.5 & 0.80 & $1.53-0.001 i$ & 0.71 & 658 & 0.11 \\
\hline
\end{tabular}

enabling the conversion between number and volume radii, and calculation of aerosol number-to-volume ratio. In this work bimodal aerosol distributions are used (i.e., $n_{\mathrm{c}}=2$ ), with the smaller mode denoted "fine" with a subscripted $\mathrm{f}$, and larger mode "coarse" with a subscripted c.

The remainder of the manuscript is organised as follows. Section 2 describes the MAN data and the method whereby aerosol number and volume can be estimated, along with associated uncertainties, and derived maps of these data. Aerosol mass is not explicitly discussed (for a given density, it is a simple scaling of aerosol volume). Section 3 provides a comparison with MODIS estimates, and Sect. 4 looks at the relationship between total columnar and surface concentrations. Finally, Sect. 5 provides a summary and outlook.

\section{Estimating columnar volume and number}

\subsection{MAN data}

The AOD measurements on MAN cruises (Smirnov et al., 2009, 2011) are made with hand-held Microtops II Sunphotometers, which allow measurement of AOD with a total (one standard deviation) uncertainty of order \pm 0.015 for typical oceanic conditions (Porter et al., 2001; Knobelspiesse et al., 2003, 2004). The instruments have five filters which can be adjusted to observe the Sun at different wavelengths; typically on MAN cruises one is used to retrieve columnar water vapour, leaving four for $\mathrm{AOD}$, in the spectral range $340 \mathrm{~nm}-1020 \mathrm{~nm}$. The overwhelming majority of measurements consist of the combination $\tau_{440}, \tau_{500}, \tau_{675}$, and $\tau_{870}$ (subscripted wavelengths are in nanometres throughout). The Ångström parameter $\alpha$ is calculated in the MAN data from a least-squares fit (in logarithmic space) of AOD and wavelength over the spectral range $440 \mathrm{~nm}-870 \mathrm{~nm}$.

Two MAN datasets are used in this work. The first is the "series average" product, where one measurement series is defined as the set of AOD measurements taken with a gap of no more than 2 min between an individual pair. The second is the "daily average" product, which is the average of all measurement series on a given day. Frequently multiple series are obtained on a given day in identical or very close locations, so visual interpretation is typically clearer using daily data, while statistical analysis benefits from the larger sample size of the series average data. In practice the results change negligibly if only one or the other data product is used, suggesting that most of the observations collected on a MAN cruise over the course of a single day sample similar aerosol regimes. In all cases, only level 2.0 (cloud-screened and quality assured) data are used.

\subsection{Calculation}

Size distribution parameters and refractive indices for the bimodal model of Sayer et al. (2012b) are given in Table 1. The free parameters, $C_{\mathrm{v}, \mathrm{f}}$ and $C_{\mathrm{v}, \mathrm{c}}$ (fine and coarse mode volumes, respectively), are determined from a least-squares fit of each set of MAN spectral AOD to the spectral extinction per unit volume modelled using Mie theory (values at the common reference wavelength of $550 \mathrm{~nm}$ are also given in Table 1), with the constraint that the volumes cannot be negative. Aerosol number can then be calculated using the ratio $C_{\mathrm{n}} / C_{\mathrm{v}}$, from Eq. (7); shown in Table 1, the ratio is 190 for the fine mode and 0.14 for the coarse.

This process is shown conceptually in Fig. 1. In this case, the observed spectral AOD (black asterisks) is best 
Table 2. Statistics of errors on spectral AOD fit using the maritime model and the MAN series-average data. Biases are defined as the fit value minus the MAN value, i.e. positive indicates the model overpredicts AOD.

\begin{tabular}{crrrr}
\hline Wavelength & $\begin{array}{r}\text { Number of } \\
\text { points }\end{array}$ & $\begin{array}{r}\text { Mean } \\
\text { bias }\end{array}$ & $\begin{array}{r}\text { Mean absolute } \\
\text { bias }\end{array}$ & $\begin{array}{r}\text { Standard deviation } \\
\text { of bias }\end{array}$ \\
\hline $340 \mathrm{~nm}$ & 3273 & -0.004 & 0.006 & 0.007 \\
$380 \mathrm{~nm}$ & 4200 & -0.0008 & 0.003 & 0.005 \\
$440 \mathrm{~nm}$ & 14504 & 0.002 & 0.005 & 0.007 \\
$500 \mathrm{~nm}$ & 15804 & -0.00007 & 0.005 & 0.008 \\
$675 \mathrm{~nm}$ & 15403 & 0.0003 & 0.004 & 0.006 \\
$870 \mathrm{~nm}$ & 15748 & -0.0005 & 0.004 & 0.005 \\
$1020 \mathrm{~nm}$ & 967 & -0.002 & 0.004 & 0.007 \\
\hline
\end{tabular}

Table 3. Number of points in each aerosol class category, as described in the text, for series-average and daily-average MAN data. Figures in parentheses indicate the number which could not be fit to the maritime aerosol model with $\chi^{2}<1$.

\begin{tabular}{lrr}
\hline Category & Series & Daily \\
\hline Total & $15804(1437)$ & $2813(177)$ \\
Maritime & $4578(253)$ & $884(50)$ \\
Dusty & $1573(267)$ & $280(33)$ \\
Continental & $9653(917)$ & $1649(94)$ \\
\hline
\end{tabular}

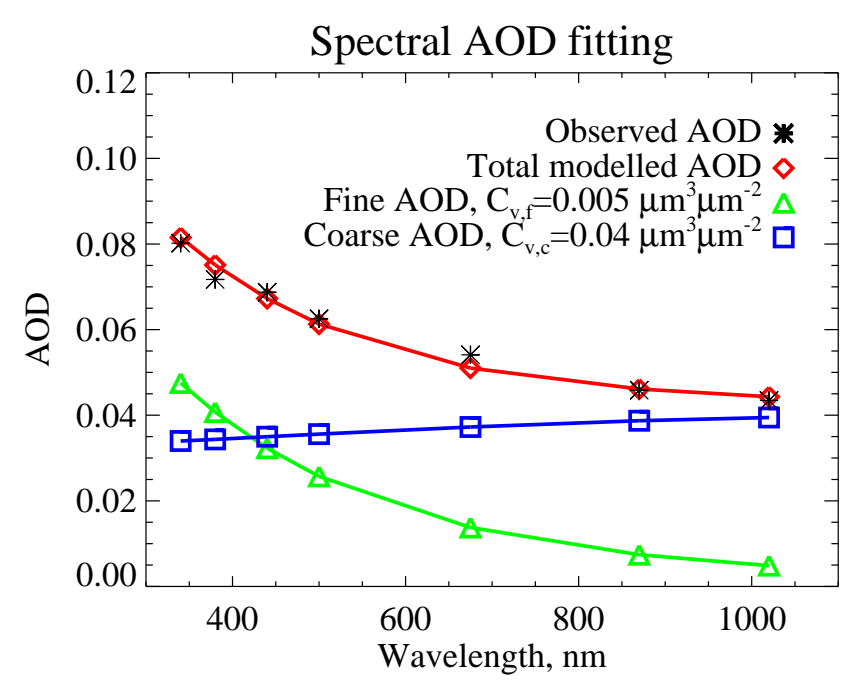

Fig. 1. Conceptual overview of fitting spectral AOD to estimate aerosol volume as a combination of fine and coarse modes.

reproduced by the combination $C_{\mathrm{v}, \mathrm{f}}=0.005 \mu \mathrm{m}^{3} \mu \mathrm{m}^{-2}$ and $C_{\mathrm{v}, \mathrm{c}}=0.04 \mu \mathrm{m}^{3} \mu \mathrm{m}^{-2}$ (total AOD given by the red curve). Note that as previously mentioned a real MAN observation would have five or fewer spectral AOD measurements, rather than the seven shown here, but this serves to illustrate the spectral dependence of the fine and coarse mode extinction across the Microtops bands.

Table 2 provides statistics on the quality with which the model is able to reproduce the spectral MAN AOD. At all wavelengths, the bias and scatter are small $(<0.01)$, particularly over the wavelength range $(440 \mathrm{~nm}-870 \mathrm{~nm})$ which was used during development of the model. Note that some of the MAN measurements contain an interpolated rather than measured $500 \mathrm{~nm}$ AOD: in these cases, this interpolated AOD was used for the statistics in Table 2 but not when performing the least-squares fit (as it did not correspond to a real measurement).

Clearly, not all of the observations in the MAN database will represent unpolluted maritime aerosol, and therefore derived aerosol volume and number may be significantly biased when this is not the case. For this reason, the MAN data have been stratified in a simple attempt to discriminate according to aerosol type, based on the AOD and $\alpha$. Three broad classes have been defined based on typical values for these parameters (e.g., Eck et al., 1999; Smirnov et al., 2004; Sayer et al., 2012b): pure maritime ( $\left.\tau_{500} \leq 0.2, \alpha \leq 1\right)$, dustinfluenced $\left(\tau_{500}>0.2, \alpha \leq 0.6\right.$ ), and fine continental (e.g., pollution/smoke or land organic)-influenced (all other points, referred to hereafter as "continental" for brevity). Additionally, as in Smirnov et al. (2012), to minimise the likelihood of continental influence in the "maritime" subset it was further required that such points be at least $200 \mathrm{~km}$ from land, using a coarse $\left(1^{\circ}\right)$ land mask as a basis (to eliminate large land masses, but not small remote islands).

Maps of these classes and fit volumes from the daily MAN data are shown in Fig. 2; the points cluster in generally expected regions, suggesting that as a first-order attempt this classification is reasonable, although there is inherently a degree of ambiguity in this type of classification. Altering these thresholds within sensible ranges does not significantly affect the spatial distribution or interpretation of results. Additionally, if the more conservative set of "pure maritime" MAN points used by Smirnov et al. (2012) is used, the results do not significantly change for this subset (which is the main focus of the analysis). Information on the sampling of these subsets is given in Table 3.

The latitudinal distribution of the number of measurement series in these three classes is shown in Fig. 3. The large abundance of the "continental-influenced" class is not suggesting that the majority of the open ocean is influenced 

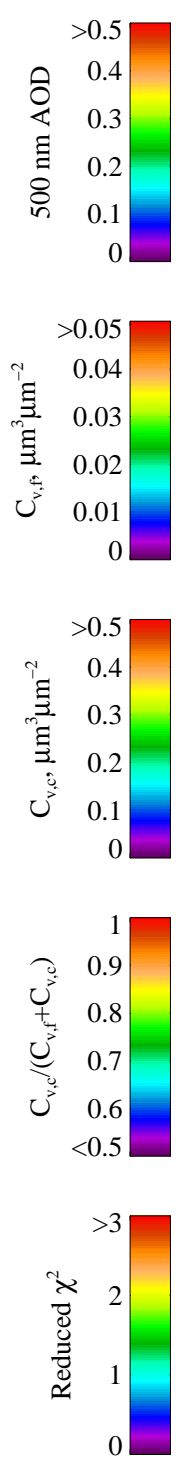

(a) Marine

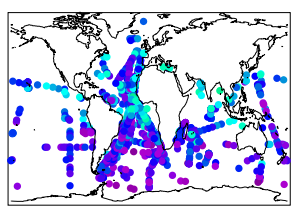

(d) Marine

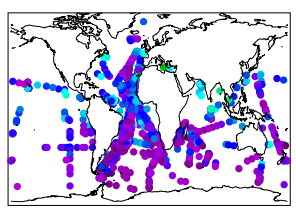

(g) Marine

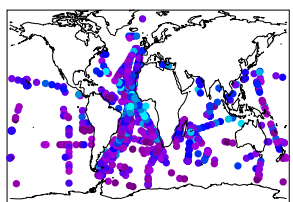

(j) Marine

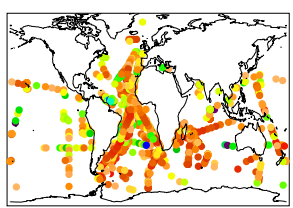

(m) Marine

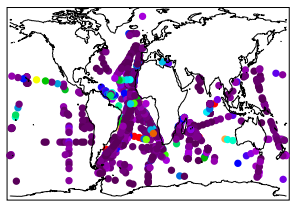

(b) Dust-influenced

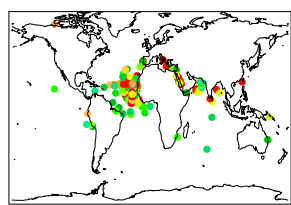

(e) Dust-influenced

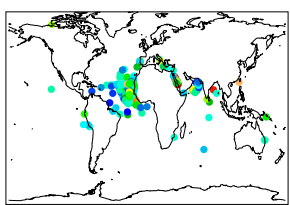

(h) Dust-influenced

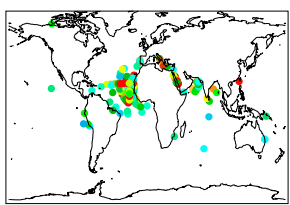

(k) Dust-influenced

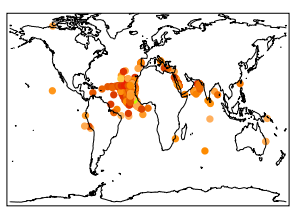

(n) Dust-influenced

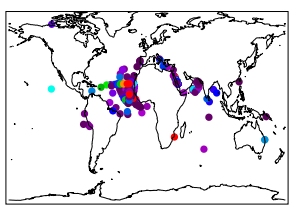

(c) Continental-influenced

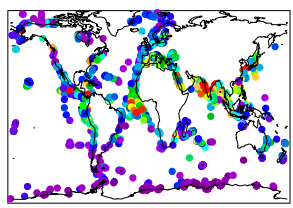

(f) Continental-influenced

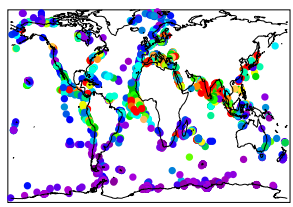

(i) Continental-influenced

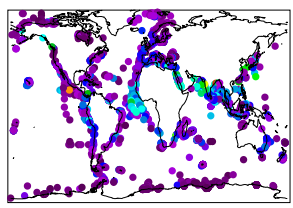

(1) Continental-influenced

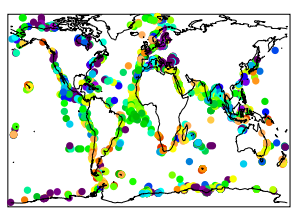

(o) Continental-influenced

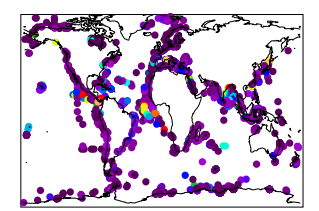

Fig. 2. Aerosol optical depth and inferred columnar aerosol volume from daily average MAN data. From left-right, columns show plots for the maritime, dusty, and continental subsets, respectively. Rows show (a-c) $500 \mathrm{~nm}$ AOD, (d-f) the fine-mode aerosol volume, (g-i) the coarse-mode aerosol volume, $(\mathbf{j}-\mathbf{l})$ fraction of aerosol volume from the coarse mode, and (m-o) the fit $\chi^{2}$.

significantly by continental outflow. Rather, this happens because of the fact that the MAN cruises begin and end on the coast, and often spend much of their time in coastal regions (Fig. 2). For example, the spike in this class at high southern latitudes comes from data collected near Antarctica. It is important to note that this "continental-influenced" classification is not purely an indicator of urban or smoke aerosol mixed with maritime aerosol (although it may contain these), but rather a catch-all for aerosol which, due to its proximity to the coast, has the potential to be influenced by land masses, and is additionally unlikely to be dominated by dust. The intent of this classification is to "protect" the "pure maritime" subset as much as possible. Again, the focus of this study is on the maritime subset for which the microphysical model is likely to be most appropriates, while the other subsets are presented for completeness and illustrative purposes.

\subsection{Uncertainty analysis}

Uncertainty in the derived aerosol colummnar volume and number concentration arises from two main sources: uncertainty in the spectral AOD used to constrain the fit fine and coarse-mode volumes, and uncertainty inherent in the assumption that the microphysical model is well-known (size distribution parameters, refractive index, and aerosol shape). These sources are discussed individually below. 


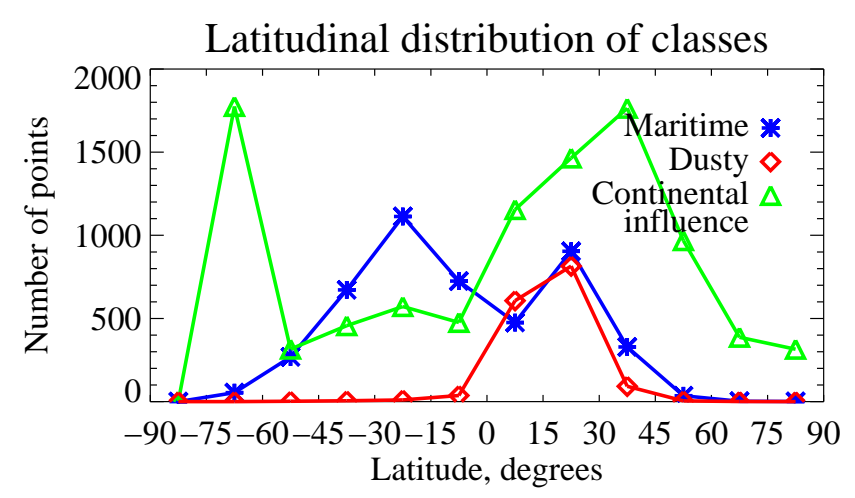

Fig. 3. Latitudinal distribution of the number of MAN measurement series falling into the maritime, dusty, and continental-influenced classifications.

\subsubsection{Uncertainty from MAN AOD}

Uncertainties in the MAN spectral AOD observations propagate into uncertainty in the fit parameters $C_{\mathrm{v}, \mathrm{f}}$ and $C_{\mathrm{v}, \mathrm{c}}$. The reduced $\chi^{2}$ statistic is used to measure the goodness of fit,

$\chi^{2}=\frac{1}{n_{\lambda}-2} \sum_{0}^{n_{\lambda}}\left(\frac{\tau_{\lambda, \text { pred }}-\tau_{\lambda, \text { MAN }}}{\sigma_{\lambda, \text { MAN }}}\right)^{2}$,

where $\tau_{\lambda, \text { MAN }}$ indicates the MAN-observed AOD, $\sigma_{\lambda \text {,MAN }}$ its uncertainty (assumed to be 0.015 and uncorrelated spectrally), $\tau_{\lambda \text {,pred }}$ the AOD predicted by the model, and $n_{\lambda}$ the number of wavelengths in the measurement series (or daily average). The factor $n_{\lambda}-2$ arises as two free parameters are fit; typically $n_{\lambda}=4$, leading to 2 degrees of freedom. The expectation of the reduced $\chi^{2}$ over a large number of samples is 1. Figure 2 also shows $\chi^{2}$ for each of the three aerosol type subsets: this is almost always less than 1 , even for those cases where the aerosol is likely not pure maritime in origin. There are two important implications of this. First, this highlights limitations in inferring aerosol type from spectral AOD (it is possible to obtain an acceptable quality of fit even if the microphysical model is incorrect). Second, this suggests that $\sigma_{\lambda, \text { MAN }}=0.015$ is not necessarily a good metric for the random error of the MAN AOD, i.e. systematic error is likely a significant component of the total uncertainty. This is also consistent with the results in Table 2, that the maritime model is able to reproduce spectral AOD with greater accuracy and precision than 0.015. Porter et al. (2001) and Knobelspiesse et al. (2004) estimate that among the largest uncertainty on Microtops AOD is the calibration gain coefficient. For a set of measurements taken on a single cruise with a single Microtops sun photometer, this is likely a systematic error, although over the whole MAN dataset (multiple instruments and calibration tests) biases may cancel out such that the errors are random.

The least-squares fit provides estimates of the uncertainty on $C_{\mathrm{v}}$ and hence $C_{\mathrm{n}}$, under the assumption that $\sigma_{\lambda \text {,MAN }}$ represents the random error on the MAN AOD. Scaling these uncertainty estimates by $\sqrt{\chi^{2}}$ provides a lower bound on the estimated uncertainty, which is under the assumption that the true value of $\sigma_{\lambda \text {,MAN }}$ is unknown and the uncertainty is therefore related to the residuals on the fit AOD. The true error on derived $C_{\mathrm{v}}$ or $C_{\mathrm{n}}$ as a result of the uncertainty on the MAN AOD is therefore likely in between these two estimates.

Relative uncertainty on $C_{\mathrm{v}}$ is shown as a function of $C_{\mathrm{v}}$ for the maritime subset of daily-average MAN AOD for both these methods in Fig. 4. As, for a given microphysical aerosol model, the aerosol number is a simple scaling to the aerosol volume (rightmost column of Table 1), these relative uncertainties also apply to the equivalent aerosol numbers. The "unscaled" points (i.e., taking $\sigma_{\lambda, \text { MAN }}=0.015$ ) typically fall into one of several curves, dependent on the selection of bands available for a particular MAN data point. The absolute uncertainty is fairly constant as a consequence of the fact that, for a given set of microphysical model parameters, AOD is linearly proportional to aerosol amount. If instead $\sigma_{\lambda, \text { MAN }}$ is assumed to be 0.01 or 0.02 , the uncertainty estimates decrease and increase by approximately $50 \%$, respectively. The "scaled" uncertainties are much more diverse but generally lower by a factor of $2-5$. For the unscaled uncertainty estimates, uncertainty on volume is around $100 \%$ for low aerosol loadings. However, the "scaled" uncertainty estimates are much lower, suggesting better sensitivity. It is worth emphasising again that the measure discussed in this section represents only the component of uncertainty due to the degree with which the MAN AOD is able to constrain the microphysical model, i.e. this is the uncertainty in derived concentrations which would be obtained if the microphysical model were perfectly known.

\subsubsection{Assumption of aerosol sphericity}

Using Mie calculations to calculate scattering and extinction properties of the aerosol relies on the assumption that the particles are spherical. Mishchenko et al. (1997b) modelled extinction for spherical and spheroidal aerosols of different size parameters and distribution widths, and found, for size parameters relevant to sea salt and dust particles in the visible and near-infrared part of the spectrum, errors of up to $15 \%$ in extinction cross section if sphericity was assumed for nonspherical particles. This therefore contributes an additional uncertainty to the dust-influenced subset of the data (which is not the main focus of the analysis).

However, Sayer et al. (2012b) found that approximately $90 \%$ of the time the relative humidity encountered during AERONET inversions at coastal sites was in the range 60$80 \%$ (from reanalysis data), and ship-borne open-ocean measurements reported a similar range to, and good agreement with, the reanalysis data. Due to hygroscopic growth (Hänel, 1976) it is likely that both fine and coarse modes of marine aerosols will have swollen to a spherical shape in these ambient conditions (e.g. Carrico et al., 2003, Wang et al., 2007), and scattering from analogues of such aerosol have 
(a) Fine mode

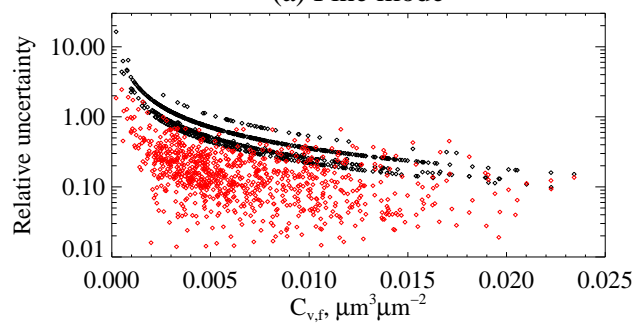

(b) Coarse mode

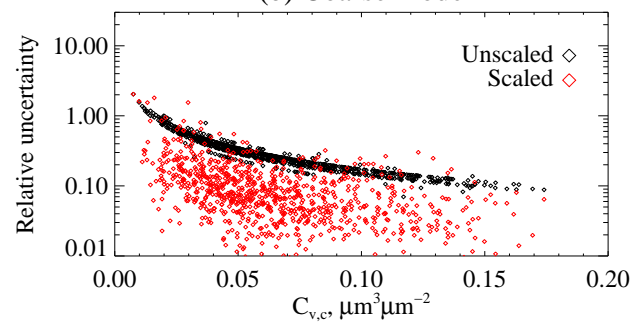

Fig. 4. Columnar aerosol volume and relative uncertainty (i.e., 1 indicates $100 \%$ uncertainty), for the marine subset of points from daily average MAN data, as a result of uncertainty in the MAN AOD. (a) shows the fine mode, and (b) the coarse mode. Black points show calculations assuming the MAN uncertainty is 0.015 , and red points where the fit $\chi^{2}$ is used to scale these uncertainty estimates.

(a) Fine mode

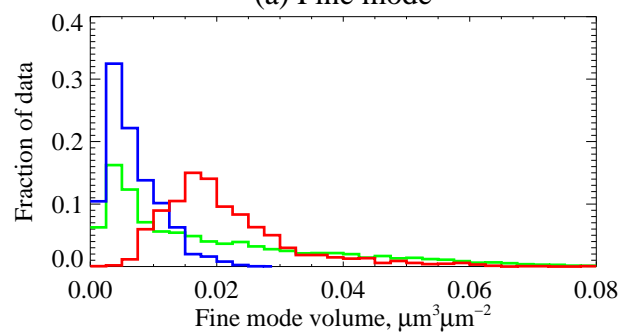

(b) Coarse mode

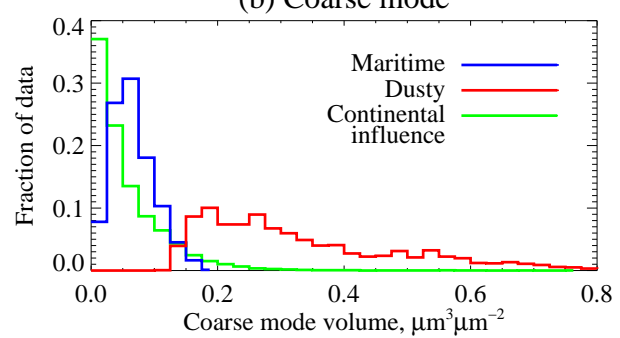

Fig. 5. Histograms of fit columnar aerosol volume for the three aerosol classes, for (a) fine and (b) coarse modes. The vertical axis indicates the number in each bin, as a fraction of the total number of points.

been found in the laboratory to be well-modelled as distributions of spherical particles (e.g. Quinby-Hunt et al., 1997). Sea salt aerosols have been observed to crystallise at very low humidities (e.g. Chamaillard et al., 2003), but this was in heated dryers, and for conditions outside the range found by Sayer et al. (2012b). Thus, for the maritime subset the assumption of sphericity is likely to introduce negligible additional uncertainty.

\subsubsection{Uncertainty from microphysical model}

As noted in Sect. 2.3.1, the observed AOD can sometimes be reproduced with reasonable precision even if the underlying microphysical model is not appropriate. Table 1 also contains information on microphysical models developed by Sayer et al. (2012a) to represent mixed maritime/continental and maritime/dust aerosols. The aerosol extinction per unit volume is generally within $20 \%$ of that for the pure maritime model across the visible part of the spectrum (only extinction at $550 \mathrm{~nm}$ is shown in Table 1), suggesting a bias of order $20 \%$ in aerosol volume if there is a non-maritime component to the aerosol and the maritime model is used. The per-particle extinction, however, shows differences in excess of $100 \%$, indicating that using the maritime model to predict aerosol number for a non-maritime aerosol would be significantly in error. For this reason, only MAN data from the maritime subset are used when aerosol number concentrations are analysed hereafter. Note that all three classes here were fit with the maritime model; the parameters from Sayer et al. (2012a) are presented here only to illustrate the potential magnitude in error of aerosol number/volume from an incorrect determination of aerosol type.

Even if the classification scheme were perfect at separating unpolluted marine aerosol from dust/continental-influenced cases, there would still be uncertainty associated with the assumptions made in the aerosol microphysical model: namely, that variability can be described by varying $C_{\mathrm{v}, \mathrm{f}}$ and $C_{\mathrm{v}, \mathrm{c}}$ while modal radii, spreads, and refractive indices are set to fixed values. Sayer et al. (2012a) found the range of variability about the mean of size distribution parameters, whether expressed as the variability at a given site or the range across bins when data were binned by meteorological parameters such as wind speed, was of order $\pm 10 \%$ for modal radius and $\pm 5 \%$ for modal spread (cf. Eq. 5). Variation in the real part of the refractive index among the literature surveyed was similarly roughly $\pm 5 \%$ (the imaginary part and its variability were generally low). Note these refractive indices are for ambient (i.e. hydrated) conditions, rather than dried aerosol particles. These ranges will encompass in an average sense the variability due to such factors as different emission sizes, residual non-marine aerosol contributions, and fluctuations in size due to hygroscopic growth and shrinking.

The sensitivity of extinction to size distribution parameters was assessed by assuming these ranges represent a two standard deviation uncertainty range in the microphysical model parameters. Then, an ensemble of 3000 new fine and coarse 
mode properties was created by adding independent Gaussian noise of the above magnitudes to the model parameters, and then recalculating the spectral per-particle and per-unitvolume extinction for each of these ensemble members (from $340 \mathrm{~nm}$ to $1020 \mathrm{~nm}$ ).

The sensitivity to such changes in model parameters is then estimated using the relative standard deviation of extinction at each wavelength among the 3000 ensemble members. For the fine mode, results showed some spectral dependence, with extinction at shorter wavelengths less affected: the relative standard deviation in per-volume extinction varied from 0.11 at $340 \mathrm{~nm}$ to 0.19 at $1020 \mathrm{~nm}$, or from 0.21 at $340 \mathrm{~nm}$ to 0.29 at $1020 \mathrm{~nm}$ when expressed in per-particle extinction. In contrast, the coarse mode showed much less sensitivity and little spectral dependence, with relative standard deviations of 0.06 in per-volume extinction and 0.14 in per-particle extinction. These, then, represent the expected relative uncertainties if the aerosol classification scheme and MAN AOD were perfect, such that the only error source were variability in the microphysical model parameters.

Since (as will be presented in the next section) the vast majority of pure marine aerosol number concentration is in the fine mode, while a majority of the volume is in the coarse mode, these results suggest that estimating aerosol volume or mass from spectral AOD should be less sensitive to microphysical model assumptions than aerosol number. Further, such uncertainty is of similar magnitude to that propagated from the uncertainty in the MAN AOD measurements (Fig. 4). This implies that to decrease the uncertainty on such estimates significantly in the future, improved constraints on both microphysical model parameters and the quantity (here, AOD) used to fit the free parameters would be needed.

González Jorge and Ogren (1996) performed a sensitivity study on the inversion of spectral AOD to retrieve the aerosol particle size distribution. In their analysis, however, they retrieved size distribution in a number of different size bins, rather than prescribing modal parameters and retrieving only total modal volumes, as in this work. This resulted in larger uncertainties in their analysis, with aerosol number often underestimated by around $80 \%$ and volume underestimated by up to $44 \%$ when a binned size distribution was retrieved. However, their study assumed no special prior knowledge of aerosol type. In this work the subsetting to cases of likely pure maritime aerosol for which microphysical model parameters and their uncertainty can be better estimated acts as a constraint to reduce the uncertainties somewhat. Nevertheless, the results of González Jorge and Ogren (1996) illustrate well that determining the aerosol size distribution from spectral AOD without extra constraints on aerosol composition is a highly underconstrained problem. General conclusions such as aerosol volume being less uncertain than number are consistent between the two studies.

One aspect of model parameter uncertainty which deserves individual mention is that of relative humidity (RH). Availability of moisture at higher humidities results in swelling of aerosol particles, increasing their volume for a given particle number, and increasing their light extinction (e.g. Hänel, 1976, Tang, 1996, Carrico et al., 2003, Wang et al., 2007). The hygroscopic growth of marine aerosol and laboratory analogues has been observed to be rapid once $\mathrm{RH}$ exceeds a deliquessence point of approximately $75 \%$, and the swelling shows a hysteresis such that crystallisation does not occur until $\mathrm{RH} \ll 50 \%$ (e.g. previously-cited references). As previously noted, Sayer et al. (2012b) found the interval $60<\mathrm{RH}<80 \%$ contained the overwhelming majority of data, and no significant dependence of microphysical model parameters on RH. It is therefore likely that any true relationship is masked by, firstly, aerosol existing in a variety of ranges of hydration due to the hysteresis of swelling and (unknown) prior history of air mass RH and, secondly, uncertainties in the RH data such as its coarse spatial resolution, or the fact that near-surface RH may not be a good indicator of the available moisture the aerosol in the total column has been exposed to. This prohibits the explicit incorporation of RH into the individual retrieved aerosol number/volume calculations in the present study, although the uncertainty is included in an average sense through the above sensitivity analysis. For a more general application outside of the marine environment, though, larger variability in $\mathrm{RH}$ would consequently lead to increased uncertainty in derived aerosol concentration if the method applied in this study were used for different aerosol types.

\subsection{Derived volume and number concentration}

For all three classes, coarse-mode volume tends to be larger than fine-mode volume by approximately a factor of 5-10 (Fig. 2); the maritime subset typically has $80 \%$ or more of total aerosol volume in the coarse mode. Relatively higher fractional coarse-mode volumes are found for the dust subset, and relatively higher fractional fine mode volumes for the continental subset, which is expected from the $\alpha$-based classification (however it is worth emphasising again that the two non-maritime subsets are subject to larger uncertainty). Histograms of aerosol volume for these three cases appear to follow approximate lognormal distributions, illustrated in Fig. 5 (using the series average MAN dataset). This is not surprising, as AOD distributions have also been observed to be lognormal (e.g., O'Neill et al., 2000 and references therein), and was also noted by Heintzenberg et al. (2000). The modes and spreads (geometric mean and geometric standard deviation, analagous to $r_{\mathrm{n}}$ and $\sigma$ in Eq. (5), respectively) are given in Table 4 , and are reasonably robust to small changes in histogram bin size. The median value of all points is also shown. As mentioned previously, volumes for the dusty and continental classes are likely to be qualitatively reliable but absolute values may have a bias of order $20 \%$.

The fine mode distribution for the continental-influenced class shows two peaks (or a very long tail); the lower-volume segment is similar to the maritime class's peak, and likely 
Table 4. Lognormal mode and spread, and median values, of relative frequency histograms of aerosol volume (for all three classes) and number (for maritime only).

\begin{tabular}{|c|c|c|c|c|c|c|}
\hline \multirow[t]{2}{*}{ Category } & \multicolumn{3}{|c|}{ Fine mode } & \multicolumn{3}{|c|}{ Coarse mode } \\
\hline & Mode & Spread & Median & Mode & Spread & Median \\
\hline Maritime (volume, $\mu \mathrm{m}^{3} \mu \mathrm{m}^{-2}$ ) & 0.0036 & 0.70 & 0.0056 & 0.047 & 0.59 & 0.062 \\
\hline Maritime (number, $\mu \mathrm{m}^{-2}$ ) & 0.71 & 0.66 & 1.07 & 0.0065 & 0.57 & 0.088 \\
\hline Dusty (volume, $\mu \mathrm{m}^{3} \mu \mathrm{m}^{-2}$ ) & 0.0160 & 0.41 & 0.0188 & 0.225 & 0.46 & 0.289 \\
\hline Continental (volume, $\mu \mathrm{m}^{3} \mu \mathrm{m}^{-2}$ ) & 0.0037 & 1.08 & 0.0136 & 0.013 & 1.09 & 0.037 \\
\hline
\end{tabular}

(a) Fine mode particle number, $\mu \mathrm{m}^{-2}$

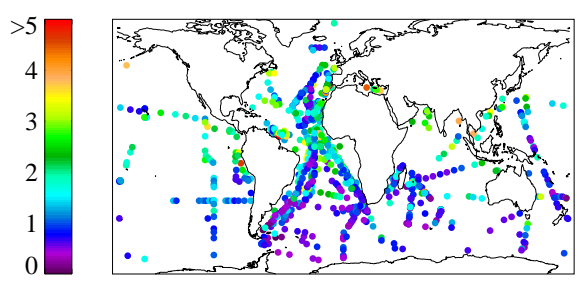

(b) Coarse mode particle number, $\mu \mathrm{m}^{-2}$

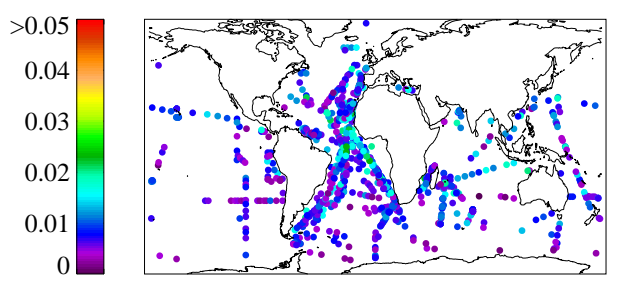

Fig. 6. Maps of fit columnar aerosol number for the maritime aerosol subset, for (a) fine and (b) coarse modes. From the daily-average MAN data.

corresponds to maritime aerosol which narrowly missed the $\tau_{500}, \alpha$, and/or land distance thresholds for inclusion in the maritime class. Both the maritime and dust-influenced distributions, however, are more distinct.

Median fine and coarse volumes for the maritime subset are $0.0056 \mu \mathrm{m}^{3} \mu \mathrm{m}^{-2}$ and $0.062 \mu \mathrm{m}^{3} \mu \mathrm{m}^{-2}$, respectively. These are similar to the average volumes found for island and coastal AERONET sites by Sayer et al. (2012b) of $0.0058 \mu \mathrm{m}^{3} \mu \mathrm{m}^{-2}$ and $0.036 \mu \mathrm{m}^{3} \mu \mathrm{m}^{-2}$ for fine and coarse modes, respectively; the higher median coarse-mode volume could be linked with increased wind-driven coarse particle emission over the open ocean. The majority of points where $\tau_{340}$ and $\tau_{380}$ are available were collected in the tropical Atlantic and fall into the "dusty" subset, and so it is possible that the small negative AOD fitting bias at these wavelengths (Table 2) and elevated fine mode volume for this subset are related to the real aerosol being more absorbing than the maritime model.

Maps of derived aerosol number (for the maritime subset only) are shown in Fig. 6, and histograms in Fig. 7. The histogram are again approximated well by a lognormal distribution (parameters in Table 4). The aerosol number:volume ratio, $C_{\mathrm{n}} / C_{\mathrm{v}}=190 \mu \mathrm{m}^{-3}$ for the fine mode (Table 1 ), is in good agreement with previous studies in the range $167-225 \mu \mathrm{m}^{-3}$ for marine aerosol (Hegg and Kaufman, 1998; van Dingenen et al., 1999; Hegg and Jonsson, 2000; Kaufman et al., 2001; Dusek et al., 2004). Dusek et al. (2004) note that in previous studies this ratio has been defined in different ways, often the ratio of total number of particles above a certain size to total volume of particles below a certain cutoff size, dependent often on the available instrumentation. As the coarse mode total aerosol number is generally only $1 \%$ or so of the fine mode number, and the coarse mode volume below the typical cutoff size used in these studies (around $1 \mu \mathrm{m}$ ) is small, it makes little difference to $C_{\mathrm{n}} / C_{\mathrm{v}}$ in this case (although $C_{\mathrm{n}} / C_{\mathrm{v}}$ would become slightly smaller and depend on the weighting between fine and coarse modes for each situation).

\section{Comparison with MODIS data}

\subsection{Data description and methodology}

The MODIS aerosol algorithm retrieves spectral AOD and $\alpha$ over ocean by mixing two aerosol components (one fine mode and one coarse mode, each from Table 1) to find the combination which matches the observed top-of-atmosphere (TOA) reflectance in six bands between $470 \mathrm{~nm}$ and $2.1 \mu \mathrm{m}$ (Tanré et al., 1997; Remer et al., 2005, 2008). Two solutions are reported in the product: namely, the combination of fine and coarse modes which most closely fit the observed TOA reflectance (hereafter the "best solution"), and the average (hereafter the "average solution") of either all solutions with a root mean square fitting error of less than $3 \%$, or the three solutions with the smallest fitting error if none are less than $3 \%$. From this, the algorithm also derives an estimate of the total columnar number of aerosol particles of radius $0.03 \mu \mathrm{m}$ or larger (Remer et al., 2005). The effect of this minimum size on the comparison is minor, as the maritime model applied to the MAN data results in fewer than $4 \%$ of the fine mode particles having a radius smaller than $0.03 \mu \mathrm{m}$.

The MODIS aerosol number estimate is to the authors' best knowledge an unvalidated quantity, although it has been 
(a) Fine mode

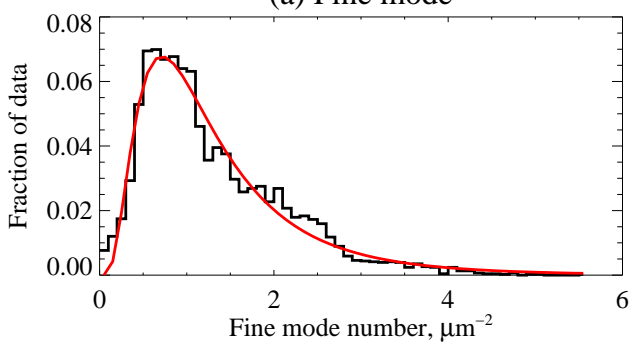

(b) Coarse mode

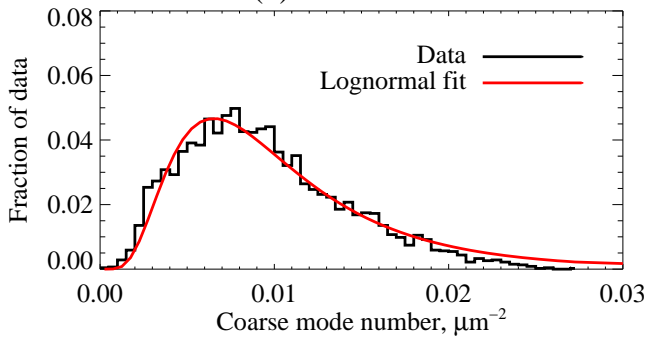

Fig. 7. Histograms of fit columnar aerosol number for the maritime aerosol subset, for (a) fine and (b) coarse modes. The vertical axis indicates the number in each bin, as a fraction of the total number of points. Black shows the binned data, and red the lognormal fit to it. From the series-average MAN data.

Table 5. Statistics of comparison between colocated MAN and MODIS $550 \mathrm{~nm}$ AOD and aerosol columnar number concentration, for the MAN measurement series identified as marine aerosol. "Best" and "average" solutions are as defined in the text. "Scaled" refers to statistics when the MODIS data are scaled to match the MAN AOD at $550 \mathrm{~nm}$. $R$ is Pearson's linear correlation coefficient and RMSD the root mean square difference. C6 statistics are given in parentheses, after C5.1 results in regular type.

\begin{tabular}{|c|c|c|c|c|}
\hline $\begin{array}{l}\text { Quantity/ } \\
\text { solution }\end{array}$ & $R$ & $\begin{array}{l}\text { Median bias } \\
\text { (MODIS - MAN) }\end{array}$ & $\begin{array}{l}\text { Median absolute } \\
\text { bias }\end{array}$ & RMSD \\
\hline \multicolumn{5}{|c|}{ MODIS Terra, QA = 1,2,3 (306 C5.1 points, 260 C6 points) } \\
\hline$C_{\mathrm{n}}, \mu \mathrm{m}^{-2}$, best & $0.26(0.39)$ & $-0.17(-0.20)$ & $0.51(0.63)$ & $1.14(1.17)$ \\
\hline$C_{\mathrm{n}}, \mu \mathrm{m}^{-2}$, average & $0.38(0.47)$ & $-0.016(-0.16)$ & $0.48(0.60)$ & $0.93(0.96)$ \\
\hline$\tau_{550}$, best & $0.74(0.77)$ & $0.027(0.020)$ & $0.028(0.025)$ & $0.046(0.036)$ \\
\hline$\tau_{550}$, average & $0.75(0.77)$ & $0.023(0.016)$ & $0.025(0.021)$ & $0.043(0.034)$ \\
\hline$C_{\mathrm{n}}, \mu \mathrm{m}^{-2}$, best, scaled & $0.35(0.43)$ & $-0.32(-0.03)$ & $0.58(0.64)$ & $1.01(1.13)$ \\
\hline$C_{\mathrm{n}}, \mu \mathrm{m}^{-2}$, average, scaled & $0.45(0.57)$ & $-0.23(-0.24)$ & $0.47(0.50)$ & $0.86(0.85)$ \\
\hline \multicolumn{5}{|c|}{ MODIS Aqua, QA = 1,2,3 (291 C5.1 points, 231 C6 points) } \\
\hline$C_{\mathrm{n}}, \mu \mathrm{m}^{-2}$, best & $0.34(0.42)$ & $0.65(0.77)$ & $1.02(1.07)$ & $1.61(1.59)$ \\
\hline$C_{\mathrm{n}}, \mu \mathrm{m}^{-2}$, average & $0.48(0.51)$ & $0.42(0.32)$ & $0.71(0.76)$ & $1.13(1.13)$ \\
\hline$\tau_{550}$, best & $0.62(0.73)$ & $0.017(0.009)$ & $0.024(0.021)$ & $0.044(0.031)$ \\
\hline$\tau_{550}$, average & $0.63(0.76)$ & $0.016(0.012)$ & $0.023(0.018)$ & $0.044(0.029)$ \\
\hline$C_{\mathrm{n}}, \mu \mathrm{m}^{-2}$, best, scaled & $0.46(0.42)$ & $0.29(0.59)$ & $0.87(1.11)$ & $1.62(1.66)$ \\
\hline$C_{\mathrm{n}}, \mu \mathrm{m}^{-2}$, average, scaled & $0.57(0.54)$ & $0.10(0.19)$ & $0.51(0.57)$ & $1.06(0.93)$ \\
\hline \multicolumn{5}{|c|}{ MODIS Terra, QA = 3 (115 C5.1 points, 191 C6 points $)$} \\
\hline$C_{\mathrm{n}}, \mu \mathrm{m}^{-2}$, best & $0.53(0.51)$ & $-0.18(-0.30)$ & $0.41(0.61)$ & $0.91(0.97)$ \\
\hline$C_{\mathrm{n}}, \mu \mathrm{m}^{-2}$, average & $0.58(0.54)$ & $-0.060(-0.24)$ & $0.43(0.58)$ & $0.79(0.88)$ \\
\hline$\tau_{550}$, best & $0.67(0.82)$ & $0.039(0.021)$ & $0.039(0.023)$ & $0.058(0.036)$ \\
\hline$\tau_{550}$, average & $0.69(0.81)$ & $0.038(0.017)$ & $0.038(0.021)$ & $0.052(0.033)$ \\
\hline$C_{\mathrm{n}}, \mu \mathrm{m}^{-2}$, best, scaled & $0.64(0.57)$ & $-0.46(-0.41)$ & $0.53(0.65)$ & $0.95(0.91)$ \\
\hline$C_{\mathrm{n}}, \mu \mathrm{m}^{-2}$, average, scaled & $0.67(0.65)$ & $-0.32(-0.31)$ & $0.46(0.51)$ & $0.82(0.77)$ \\
\hline \multicolumn{5}{|c|}{ MODIS Aqua, QA = 3 (97 C5.1 points, 96 C6 points) } \\
\hline$C_{\mathrm{n}}, \mu \mathrm{m}^{-2}$, best & $0.42(0.50)$ & $1.21(0.77)$ & $1.29(1.00)$ & $1.94(1.73)$ \\
\hline$C_{\mathrm{n}}, \mu \mathrm{m}^{-2}$, average & $0.64(0.61)$ & $0.85(0.44)$ & $0.85(0.68)$ & $1.32(1.16)$ \\
\hline$\tau_{550}$, best & $0.49(0.85)$ & $0.037(0.018)$ & $0.039(0.028)$ & $0.059(0.032)$ \\
\hline$\tau_{550}$, average & $0.48(0.86)$ & $0.028(0.017)$ & $0.035(0.021)$ & $0.059(0.028)$ \\
\hline$C_{\mathrm{n}}, \mu \mathrm{m}^{-2}$, best, scaled & $0.62(0.47)$ & $0.62(0.67)$ & $0.90(1.08)$ & $1.61(1.84)$ \\
\hline$C_{\mathrm{n}}, \mu \mathrm{m}^{-2}$, average, scaled & $0.79(0.62)$ & $0.35(0.24)$ & $0.46(0.51)$ & $0.96(0.98)$ \\
\hline
\end{tabular}


Table 6. Fraction of MODIS-MAN matchups with an AOD at $550 \mathrm{~nm}$ within the expected MODIS absolute error of $0.03+5 \%$ of the MAN value.

\begin{tabular}{lllll}
\hline \multirow{2}{*}{$\begin{array}{l}\text { Sensor/QA } \\
\text { threshold }\end{array}$} & \multicolumn{2}{c}{ Best solution } & \multicolumn{2}{l}{ Average solution } \\
& C5.1 & C6 & C5.1 & C6 \\
\hline Terra, QA $=1,2,3$ & 0.60 & 0.71 & 0.62 & 0.74 \\
Terra, QA =3 & 0.41 & 0.72 & 0.46 & 0.77 \\
Aqua, QA $=1,2,3$ & 0.66 & 0.73 & 0.71 & 0.78 \\
Aqua, QA =3 & 0.45 & 0.71 & 0.52 & 0.76 \\
\hline
\end{tabular}

used, examined, or compared with other data in several studies (Gassó and Hegg, 2003; Li et al., 2010; Kaskaoutis et al., 2011; Krüger and Graß1, 2011). In contrast, the AOD over ocean has been compared more thoroughly with other satellite and ground-based datasets and its strengths and limitations are fairly well-understood (e.g., Zhang and Reid, 2006; Mishchenko et al., 2007, 2010; Remer et al., 2008; Kahn et al., 2009, 2011; Shi et al., 2011; Smirnov et al., 2011; Kleidman et al., 2012; Sayer et al., 2012a, and others). The MAN-derived data here are also subject to some uncertainties as discussed previously, so while a comparison between aerosol number from these two datasets cannot be considered a validation against ground truth, it does allow for an examination of their consistency and, hopefully, an understanding of their differences.

Matchups between MODIS and the MAN data are performed by averaging MODIS retrievals within $25 \mathrm{~km}$ of a MAN measurement separated in time by 30 min or less. In almost all cases, variability in MODIS AOD in this $25 \mathrm{~km}$ circle was small, and the same aerosol model was chosen as the "best solution" for each retrieval. Only MAN data defined previously as belonging to the maritime subset are considered, as $C_{\mathrm{n}}$ from others is expected to be less reliable. The AOD is compared at the standard reference wavelength of $550 \mathrm{~nm}$, as provided in the MODIS product; interpolation of the MAN data to this wavelength using the Ångström power law (Eq. 3) introduces negligible uncertainty.

As well as the present Collection 5.1 (hereafter C5.1), results are presented using the forthcoming Collection 6 (C6) algorithm. C6 products should become available around the end of 2012. The over-ocean algorithmic concept is the same in C6 as C5.1, but there are changes related to gaseous transmittance corrections, improved masking of cirrus clouds, accounting for wind-speed dependence of Sun glint and oceanic whitecaps (which will decrease retrieved AOD in high-wind environments; Sayer et al., 2010; Shi et al., 2011; Kleidman et al., 2012), and definitions of quality flags. Sensor calibration will also be updated for C6 but final coefficients are not available at the time of writing (i.e., these results use $\mathrm{C} 5$ radiometric calibration coefficients), and the impact over open ocean (on retrieved AOD at least) is expected to be small.

\subsection{Results}

Some statistics of the comparison of AOD and aerosol number are presented in Table 5, considering both the MODIS sensors on board the Terra and Aqua platforms, and for either the highest quality assurance $(\mathrm{QA})$ flag $(\mathrm{QA}=3)$ or the looser criteria of $\mathrm{QA}=1,2$, or 3 (almost no retrievals were assigned $\mathrm{QA}=2$ ). Scatter plots of the $\mathrm{QA}=3$ data are shown in Fig. 8, and maps for the "best" solution in Fig. 9, both for C5.1 data. Table 6 shows the fraction of MODISMAN matchups with an AOD at $550 \mathrm{~nm}$ within the expected MODIS absolute error (Remer et al., 2008) of $0.03+5 \%$ of the MAN value. Looking first at $\tau_{550}$, there is a tendency for MODIS to overestimate as compared to the MAN data, and Terra to be higher than Aqua by around 0.01, as noted in previous studies (e.g., Remer et al., 2008; Shi et al., 2011; Smirnov et al., 2011). The bias is reduced by typically $30 \%-50 \%$ in C6 as compared to C5.1, and the fraction of matchups within the expected error increases. The issues which the $\mathrm{C} 6$ algorithm updates were primarily designed to address (i.e. cirrus cloud contamination, wind speed-related biases) are likely to manifest most acutely in clean conditions when the AOD is small, such as those selected for in this study. The improvement in the AOD comparison observed with C6 data therefore suggests these efforts have met with some success.

A second set of comparisons of derived $C_{\mathrm{n}}$ have been performed, where the MODIS values have been scaled by the ratio of MAN to MODIS AOD at $550 \mathrm{~nm}$ (i.e., if MODIS overestimated MAN AOD by $20 \%$, the MODIS $C_{\mathrm{n}}$ would be decreased by a corresponding amount). This "scaled" $C_{\mathrm{n}}$ allows a first-order separation between the effects of differences in AOD and differences in aerosol microphysical model assumptions on the comparison. Tables 5 and 6 also show that restricting the data to $\mathrm{QA}=3$ (the retrievals with highest confidence) results in a poorer agreement of AOD (and also $C_{\mathrm{n}}$ ) between the datasets. However, these results should not necessarily be expected to apply to the MODIS dataset as a whole, as the $\mathrm{QA}=3$ subset is comparatively small (about a factor of 3 fewer points than the $\mathrm{QA}=1,2,3$ case for C5.1), and these comparisons only consider MAN data from the maritime subset, which is a small proportion of the total dataset. The MODIS over-ocean data usage recommendation is that retrievals of QA 1, 2, or 3 are likely of similar quality and all suitable for analysis, which is consistent with these comparisons (Remer et al., 2005, 2008). The total number of C6 points is smaller than C5.1, likely due to stricter cloud screening, and $\mathrm{QA}=3$ becomes more common. Irrespective of QA threshold, the differences between "best" and "average" solutions, and scaled and unscaled AOD, are broadly similar.

Relative to MAN-derived data, MODIS Terra tends to underestimate and Aqua to overestimate $C_{\mathrm{n}}$ (Table 5). The regional sampling of the two datasets is similar (Fig. 9), suggesting these differences are more related to the retrieval than 


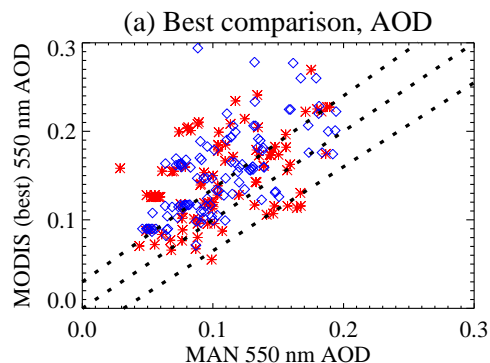

(d) Average comparison, AOD

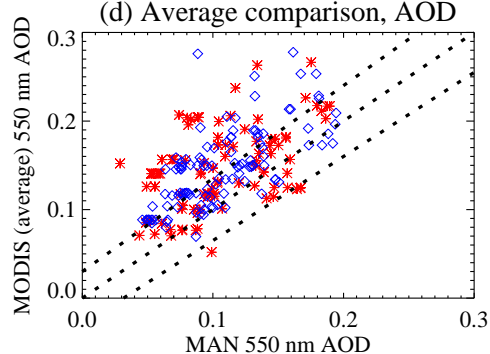

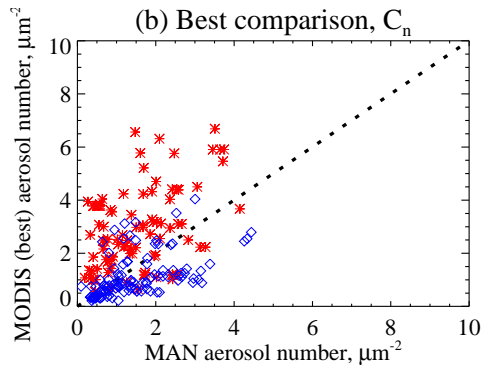

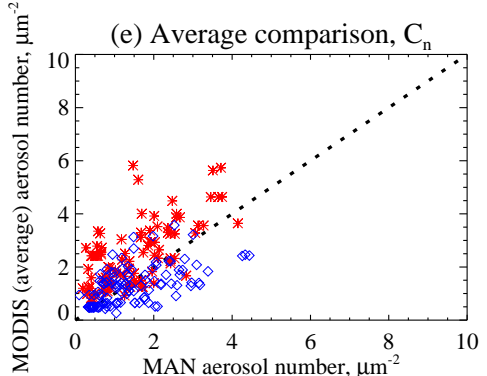

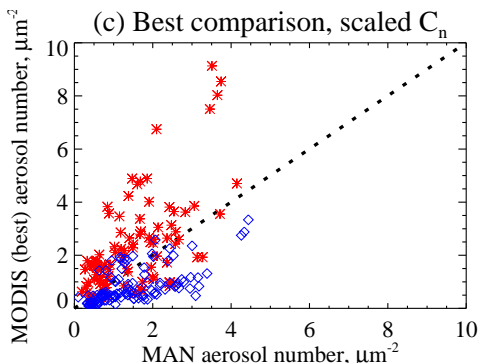

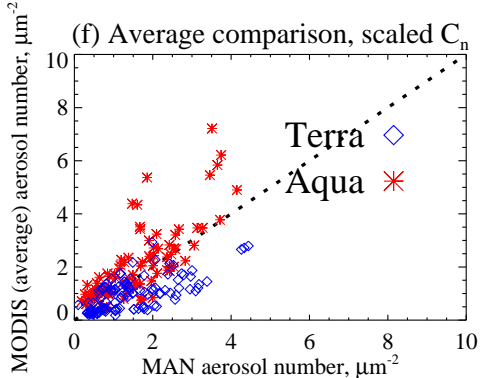

Fig. 8. Comparison between MAN and MODIS-derived AOD and $C_{\mathrm{n}}$, from MODIS Collection 5.1. The top row (a-c) shows the MODIS "best" solution, and the bottom row (d-f) the "average" solution. Panels show comparisons between (a, d) AOD at 550 nm (outer dashed lines show the MODIS expected error envelope of $0.03+5 \%) ;(\mathbf{b}, \mathbf{e}) C_{\mathrm{n}}$; and (c, f) $C_{\mathrm{n}}$ scaled to the value which would be reported if MODIS and MAN AOD matched at $550 \mathrm{~nm}$.

(a) MAN particle number, $\mu \mathrm{m}^{-2}$
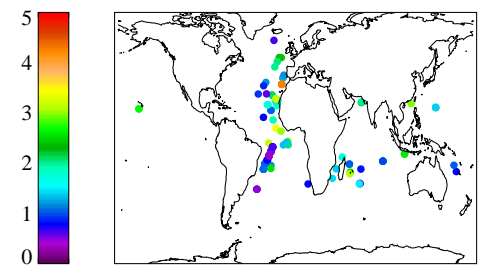

(d) MAN particle number, $\mu \mathrm{m}^{-2}$
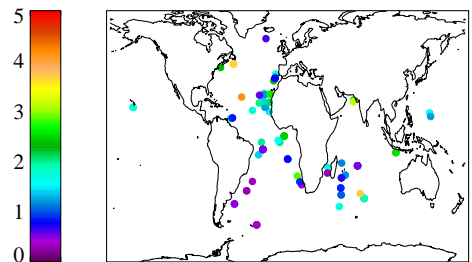

(b) Terra (best)-MAN, $\mu m^{-2}$
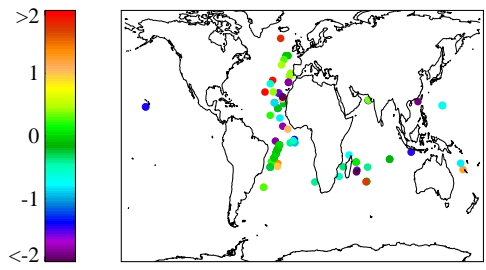

(e) Aqua (best)-MAN, $\mu \mathrm{m}^{-2}$
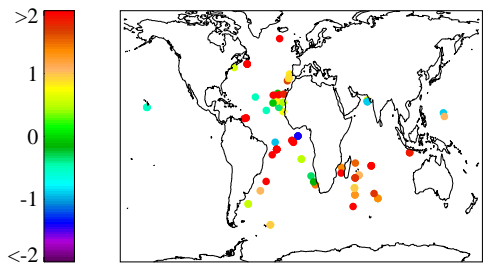

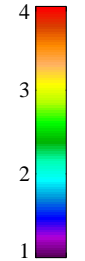

(c) Terra (best) fine mode index

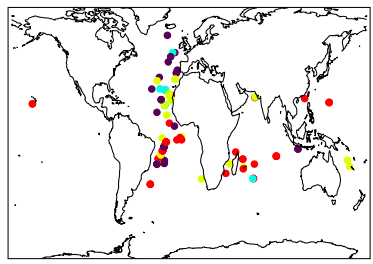

(f) Aqua (best) fine mode index

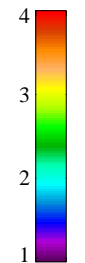

Fig. 9. Locations and statistics of MODIS and MAN-derived $C_{\mathrm{n}}$, for QA $=3$ MODIS retrievals and the "best" MODIS solution. The top row (a-c) shows data for MODIS Terra, and the bottom row (d-f) MODIS Aqua, from MODIS Collection 5.1. Panels show (a, d) the MANderived $C_{\mathrm{n}} ;(\mathbf{b}, \mathbf{e})$ the MODIS-MAN $C_{\mathrm{n}}$ difference; and $(\mathbf{c}, \mathbf{f})$ the index of the fine aerosol mode (Table 1) MODIS reported as providing the "best" solution.

spatial sampling. Performing the AOD-based scaling tends to reduce the absolute and root mean square differences between MAN and MODIS data; however, significant differences remain in this case, indicating microphysical model assumptions play a role. Further, large differences of either sign between the datasets are not confined to continental outflow areas, suggesting that errors in MAN $C_{\mathrm{n}}$ from non-maritime influences are not the primary cause for difference.
Table 1 shows that, as is the case for the maritime aerosol model of Sayer et al. (2012b), the fine mode per-particle extinction is around two orders of magnitude smaller than the coarse mode, and so the total $C_{\mathrm{n}}$ will be determined largely by fine mode abundance. MODIS fine mode \#2 has a similar per-particle extinction and $C_{\mathrm{n}} / C_{\mathrm{v}}$ to the model of Sayer et al. (2012b), so if the two datasets report the same AOD and this fine mode is picked in the MODIS dataset, the two estimates 
of $C_{\mathrm{n}}$ should be close (although the partition between fine and coarse modes to the total AOD in both datasets will remain a factor).

However, Fig. 9 shows that MODIS fine mode \#2 is rarely picked as the "best" solution by either Terra or Aqua. Instead, Terra has a tendency to more frequently pick \#3 or \#4, and Aqua \#1, which have lower (for Terra) or higher (for Aqua) $C_{\mathrm{n}} / C_{\mathrm{v}}$ (and the reverse for per-particle extinction) than the maritime model applied to MAN data. This will be responsible for the relative overestimate of Aqua and underestimate of Terra as compared to MAN. As the same algorithm is applied to both MODIS sensors, it seems reasonable to suspect that the differences in typical model choice between the two sensors could be linked with small systematic differences in their radiometric calibration; as the AOD is low for these cases, determination of size-related aerosol information is an inherently difficult task which is more sensitive than total AOD to uncertainties and errors. Diurnal changes between the local overpass times of the sensors (10:30 am vs. 1:30 pm) may also contribute. These conclusions hold for both C5.1 and C6 (although it is likely that aerosol model selection will be more sensitive than total AOD to radiometric calibration changes which may be applied in the final C6 data).

The "average" MODIS solution matches MAN data closer than the "best" solution, for both AOD and $C_{\mathrm{n}}$ (Table 5), with higher correlations and smaller biases/absolute differences. This is likely because the averaging of several solutions reduces both retrieval noise and the effect of aerosol microphysical model assumptions on the retrieval. Although the MAN-derived $C_{\mathrm{n}}$ are not a "ground truth" for the satellite retrievals, these results suggest that the MODIS "average" solution may provide a better estimate of AOD and $C_{\mathrm{n}}$ for unpolluted maritime aerosol than the "best" solution.

The mean and median MAN $550 \mathrm{~nm}$ AOD for the set of matchups with MODIS is approximately 0.1 . An expected MODIS uncertainty in AOD of $0.03+5 \%$ suggests on average approximately an $80 \%$ relative error. Dependent on QA threshold, sensor, data version, and "best"/“average" solution filtering, the median relative difference between MAN and MODIS number concentration estimates is between approximately $50 \%$ and $90 \%$ (Terra on the lower end, Aqua on the higher, "best" better than "average" solutions). This does not change appreciably when the scaled MODIS number estimates described above (i.e. forcing agreeement in $550 \mathrm{~nm}$ AOD) are used. Inferences from this are either that the uncertainty on the MAN-derived estimates is a significant contribution to the differences in number concentration (which, given Sect. 2.3, is likely the case), and/or that, at least for these clean maritime conditions, the uncertainty on MODIS-derived number concentration is largely independent of that on retrieved $550 \mathrm{~nm}$ AOD (perhaps mostly dependent on aerosol microphysical model assumptions).

\section{Estimating surface concentration}

\subsection{Assuming a vertical profile}

The previous sections have dealt with columnar aerosol number and volume, as the MAN AOD measurements represent the column extinction. Determination of surface concentration requires knowledge of the vertical profile. In a generalised case, the vertical distribution could be assumed as some well-mixed layer above which number concentration decreases exponentially with height,

$n(z)= \begin{cases}n_{0} & 0<z<d \\ n_{0} e^{(d-z) / h} & d<z<\infty\end{cases}$

where $n(z)$ is the number concentration at altitude $z, n_{0}$ the surface concentration, $d$ the depth of the well-mixed layer, and $h$ the scale height. Then, by definition,

$C_{\mathrm{n}}=\int_{0}^{d} n_{0} \mathrm{~d} z+\int_{d}^{\infty} n_{0} e^{(d-z) / h} \mathrm{~d} z$,

which can be solved to give

$n_{0}=\frac{C_{\mathrm{n}}}{d+h}$,

i.e. the surface concentration for this type of profile is dependent on $d+h$, the sum of the well-mixed layer depth and the scale height, and not the partition between them. For example, for a given $C_{\mathrm{n}}$, taking $h=1.5 \mathrm{~km}, d=0.5 \mathrm{~km}$ gives the same $n_{0}$ as $h=1 \mathrm{~km}, d=1 \mathrm{~km}$ or $h=2 \mathrm{~km}, d=0 \mathrm{~km}$. Hereafter, $d+h$ will be referred to as the "characteristic height".

Table 7 presents results from several studies (mostly airborne measurements of the lower troposphere) suggesting that marine aerosol is often observed to show an approximately exponentially decreasing number profile with height. Many of these studies do not sample the lowest few hundred metres or so of the atmosphere, so profiles showing a scale-height type shape should then intuitively have $d$ smaller than a few hundred metres. From these observations, $d+h \approx 1.5 \mathrm{~km}$ seems to be a reasonable default assumption, although the typical range in Table 7 (scale heights 1-2 km, a few around $0.5 \mathrm{~km}$ ) will lead to around a factor of 2 variability in derived $n_{0}$, highlighting the uncertainty in estimating surface concentration. Additionally, Table 8 shows that profiles other than exponentially-decreasing with height are also observed for marine aerosol. The available field campaign data are from limited regions and study periods, and it is difficult to assess how common such profiles are on a wider scale, given the present diversity in CTM estimates (e.g. Yu et al., 2010, Koffi et al., 2012). All that can be said is that, for marine aerosols, both exponential and non-exponential profiles appear to be common. 


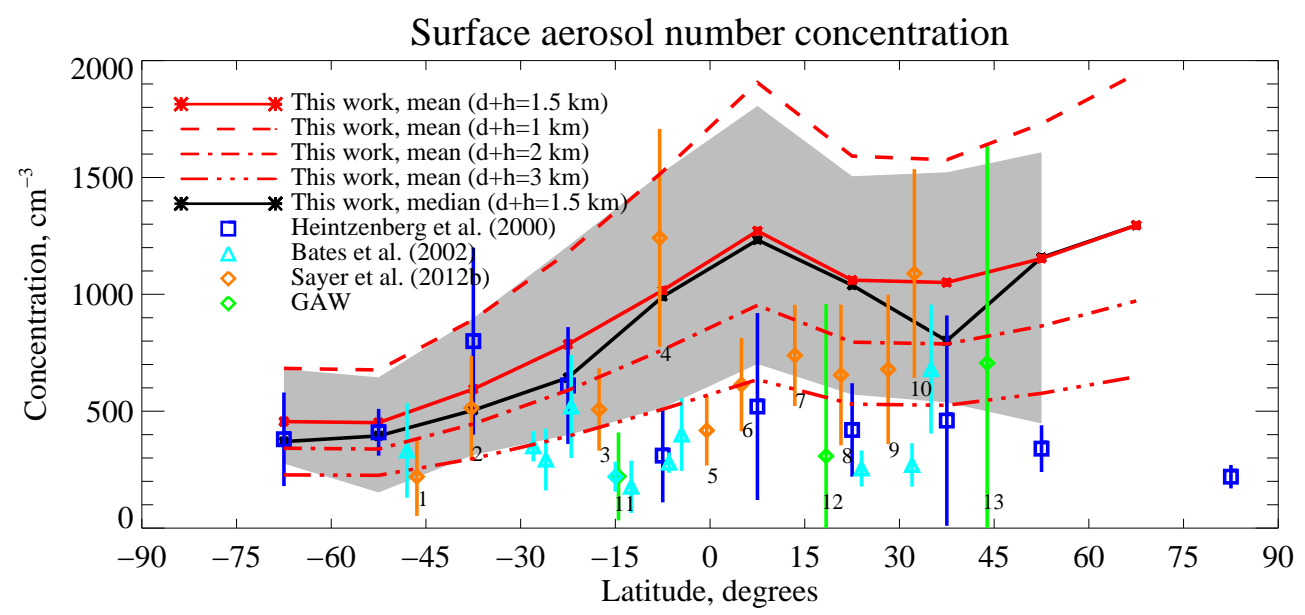

Fig. 10. Zonal estimates of aerosol surface number concentration from MAN data, from the maritime subset of the daily average dataset. The mean is shown in red and median in black, and the shaded grey area indicates the central $68 \%$ of the data (for latitude ranges with more than one point), assuming a characteristic height of $1.5 \mathrm{~km}$. Dashed and dot-dashed red lines indicate the mean profile if other characteristic heights are used instead. Coloured open symbols show different comparative datasets, as described in the text, with error bars indicating the variability on the data (typically standard deviation) as quoted in the relevant references. Numbers below AERONET (Sayer et al., 2012b) and GAW points indicate stations as follows: 1, Crozet Island; 2, Amsterdam Island; 3, Tahiti; 4, Ascension Island; 5, Nauru; 6, Kaashidhoo; 7, Guam; 8, Lanai; 9, Midway Island; 10, Bermuda; 11, Samoa; 12, Cape San Juan; 13, Sable Island.

To propagate columnar quantities to surface quantities in this way also requires the assumption that the aerosol composition is invariant through the column, which may not always be true (although for low-lying marine aerosols is likely more appropriate than for other types). Still, assuming vertical homogeneity of composition and taking $d+h=1.5 \mathrm{~km}$ can provide a first-order estimate to examine average behaviour, in the absence of independent information on a caseby-case basis. Again, in cases of different non-marine aerosol systems such as transported dust or smoke layers, the complexity of the (unknown) aerosol vertical profile would likely make such efforts near-impossible. It is worth emphasising that such an approximation can only be expected to hold in an average sense, to give an illustrative example of surface number concentrations, rather than for a specific case, and again that the exponential profile is only an approximation which may be more or less appropriate for any given location and time.

\subsection{Illustrative comparison}

Unfortunately, direct comparison of MAN-derived estimates with in situ data is difficult due to a paucity of directly colocated data. However, general tendencies can be examined. Figure 10 shows a comparison between boundary layer aerosol number concentrations calculated from the maritime subset of the MAN data with other measurements and retrievals. These are intended to provide additional insight into typical values and spatial/temporal variability in different regions.
The first of these is a collation of various field campaigns by Heintzenberg et al. (2000); the characteristic height used to convert the MAN column amounts to surface concentrations here $(d+h=1.5 \mathrm{~km})$ corresponds to the typical satellite-derived scale height reported by Yu et al. (2010) for the geographical areas in which the data of Heintzenberg et al. (2000) were collected. MAN-derived latitudinal profiles for heights of $1 \mathrm{~km}$ and $2 \mathrm{~km}$ are also given, to illustrate the magnitude of systematic uncertainty possible from scale height changes in this range. Field campaign measurements identified as belonging to maritime air masses by Bates et al. (2002) are also shown.

The World Meteorological Organisation (WMO) Global Atmosphere Watch (GAW) provide multiannual statistics of aerosol surface number concentration for multiple monitoring stations at http://ebas.nilu.no; shown here are multiannual median values and standard deviations for three lowlying island sites (Samoa, $14.5^{\circ} \mathrm{S}$; Cape San Juan, $18.3^{\circ} \mathrm{N}$; Sable Island, $43.9^{\circ} \mathrm{N}$ ). Medians are used as it is likely these sites sometimes sample non-maritime air masses (so the median is likely a better estimate of the baseline maritime than the mean).

Finally, bimodal lognormal fits to median AERONET size distribution inversions representing maritime conditions at eleven sites were used by Sayer et al. (2012b) to constrain the maritime aerosol microphysical model applied in this work. These distributions have been used to calculate total columnar and then surface number concentration (again for a characteristic height of $1.5 \mathrm{~km}$ ), and also shown in Fig. 10. The error bars for these points are taken using the relative standard deviation of $\tau_{440}$ at each site scaled to the total 
Table 7. Scale heights for marine aerosol, from various sources.

\begin{tabular}{|c|c|c|c|}
\hline Reference & Scale height, $\mathrm{km}$ & Region & Note/origin in reference \\
\hline \multirow[t]{2}{*}{ Yu et al. (2010) } & $0.5-1.5$ & Global & $\begin{array}{l}\text { Fig. 6, Cloud-Aerosol Lidar with Or- } \\
\text { thogonal Polarization (CALIOP) pro- } \\
\text { files. Open ocean. }\end{array}$ \\
\hline & $1.5-2.5$ & Global & Continental outflow regions. \\
\hline \multirow[t]{2}{*}{ Clarke and Kapustin (2002) } & $\sim 2.2$ & Pacific & $\begin{array}{l}\text { Fig. } 13 \text {; continentally-influenced air } \\
\text { masses. }\end{array}$ \\
\hline & $\sim 1$ & & Fig. 13; clean air masses. \\
\hline Clarke et al. (2001) & $\sim 1.5-2$ & Hawaii & $\begin{array}{l}\text { Figs. } 1 \text { and 3; polluted/dusty air masses, } \\
\text { evidence of some distinct layers. }\end{array}$ \\
\hline \multirow[t]{2}{*}{ Schmid et al. (2000) } & $\sim 0.8$ & Canary Islands & $\begin{array}{l}\text { Fig. 2; also Figs. } 3 \text { and } 6 \text { of Gassó et al. } \\
(2000) \text {. }\end{array}$ \\
\hline & $\sim 0.9$ & Canary Islands & Fig. 10. \\
\hline Livingston et al. (2000) & $\sim 0.9$ & Coastal N. Atlantic & Fig. 4 ; little variability in lowest $0.4 \mathrm{~km}$. \\
\hline Russell et al. (1999a,b), & $\sim 1-1.5$ & US coast (Virginia) & Plate 1 of Russell et al. (1999b). \\
\hline \multirow[t]{2}{*}{ Hegg et al. (1996) } & $0.13-0.52$ & US coast (California) & $\begin{array}{l}\text { Table 5; some measurements sampled } \\
\text { very limited altitude ranges. }\end{array}$ \\
\hline & $0.25-1.11$ & US coast (Washington) & \\
\hline Kristament et al. (1993) & $\sim 1.5$ & Southwest Pacific & Fig. 1. \\
\hline Fitzgerald (1989) & $\sim 0.25-1.2$ & - & $\begin{array}{l}\text { Fig. } 5 \text {; theoretical calculations for rela- } \\
\text { tive humidities between } 52 \% \text { and } 85 \% \text {. }\end{array}$ \\
\hline Yershov et al. (1988) & 1.7 & Black Sea & Helicopter measurements. \\
\hline Blanchard and Woodcock (1980) & $\sim 1$ & Atlantic, Pacific & $\begin{array}{l}\text { Fig. } 7 \text {; wind speeds of } 8 \mathrm{~ms}^{-1} \text { and } 14 \\
\mathrm{~ms}^{-1} \text {. Coarse mode particles only. }\end{array}$ \\
\hline \multirow[t]{2}{*}{ Patterson et al. (1980) } & $\sim 0.5$ & Pacific & Fig. 6; large particles. \\
\hline & $\sim 1$ & & Small particles. \\
\hline \multirow[t]{2}{*}{ Sturm (1980) } & $1.1-2$ & - & $\begin{array}{l}\text { Eq. }(11.22) \text { in lower troposphere; range } \\
\text { for } 50 \mathrm{~km} \text { visibility }(1.1 \mathrm{~km}) \text { to } 10 \mathrm{~km} \\
\text { visibility }(2 \mathrm{~km}) \text {. }\end{array}$ \\
\hline & & & $\begin{array}{l}\text { Based on McClatchey et al. (1972) pro- } \\
\text { files. }\end{array}$ \\
\hline Sebacher et al. (1967) & $\sim 1.5$ & US coast (Virginia) & Fig. 3 (bottom). \\
\hline
\end{tabular}

Table 8. Marine aerosol vertical profiles which are not well-represented with exponentially-decreasing vertical profiles, from various sources.

\begin{tabular}{lll}
\hline Reference & Region & Profile/origin in reference \\
\hline Sharma et al. (2011) & Hawaiian coast & Fig. 2; drop up to $\sim 100 \mathrm{~m}$ and above $\sim 1 \mathrm{~km}$, fairly flat between. \\
Welton et al. (2002) & Indian Ocean & Figs. 9 and 13; peak $\sim 0.5 \mathrm{~km}$, decay above and below. \\
Voss et al. (2001) & Atlantic & Fig. 7; increasing from surface, capped at $1 \mathrm{~km}$. \\
Clarke et al. (1997) & Atlantic & Fig. 9; distinct layer up to $\sim 0.6 \mathrm{~km}$. \\
Blanchard and Woodcock (1980) & Atlantic, Pacific & Fig. 7; wind speeds of $1 \mathrm{~ms}^{-1}$ and $3.5 \mathrm{~ms}^{-1}$. \\
Sebacher et al. (1967) & US coast (Virginia) & Little vertical variation. Coarse mode particles only. \\
& &
\end{tabular}

aerosol particle number, the rationale being that this wavelength is most sensitive to fine-mode particles. One site (Graciosa, $39.1^{\circ} \mathrm{N}$ ) falls outside the scale at an estimated surface aerosol particle concentration of $3000 \mathrm{~cm}^{-3}$; Sayer et al. (2012b) noted a higher fine-mode abundance here than at other sites, and speculated some contribution from a local aerosol source.

Poleward of $20^{\circ} \mathrm{S}$, there is good agreement between the datasets. However, through the tropics and Northern Hemi- sphere the MAN-derived estimates are generally higher than the in situ data. Taking $d+h=3 \mathrm{~km}$ (also shown) is required to get a reasonable average agreement in this region. Figure 11 shows the characteristic height required for the latitidunal average MAN-derived and ground site surface aerosol number concentrations to match. Although there are only a small total number of points (33), there appear to be two main peak regions, with heights of $1.5-2.5 \mathrm{~km}$ and $3.5-$ $4.5 \mathrm{~km}$. Note that, because of the locations of the ground sites 
Heights for MAN and ground data to match

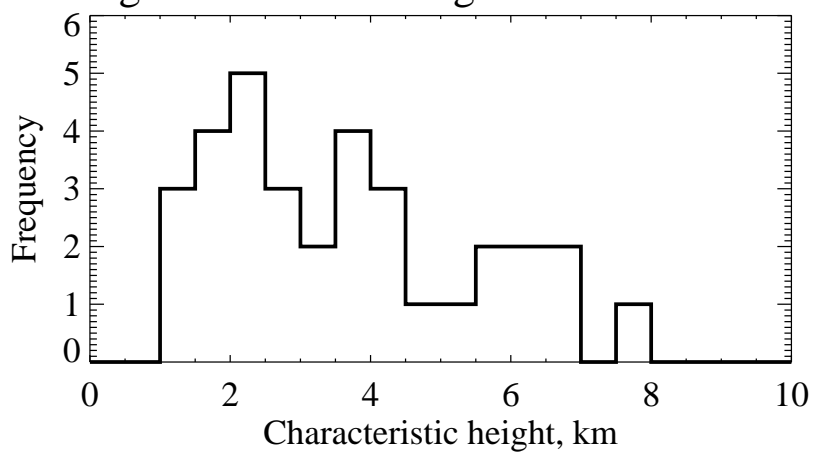

Fig. 11. Frequency histogram of characteristic heights required for MAN-derived latitudinal average aerosol surface number concentration to match ground-based (Fig. 10) number concentrations. The bin size is $0.5 \mathrm{~km}$.

in Fig. 10, tropical regions are overrepresented in this histogram.

There are multiple reasons why this regional dependence of agreement could be observed. For the points poleward of $20^{\circ} \mathrm{S}$, it could be that the characteristic height chosen is appropriate and the aerosol is maritime in nature. Further north of this, land means there may be an increased influence of continental air masses and so the maritime model is less appropriate. Table 1 shows that discrepancies of this magnitude are possible due to uncertainty in aerosol microphysical properties. Variability of scale height in different ocean basins or latitude regions may also contribute. The majority of MAN tropical maritime cases are in the open Atlantic Ocean; much of the data collected and shown in Table 7 is for the coastal Atlantic or Pacific Oceans. Non-coincidence of sampling (both spatial and temporal) is likely an important factor, as variabilities within each latitude range, and at individual sites averaged over time, are large. A further possibility in the tropics is contamination by thin cirrus, which can be widespread and not always detected by ground-based instrumentation, leading to a positive bias in the MAN AOD and $n_{0}$ (Chew et al., 2011).

Instrumental artefacts such as incomplete sampling of the aerosol size distribution (poor sampling efficiency in some size ranges) can also be a factor leading to underestimates of aerosol number in the in situ data (e.g. Reid et al., 2006 for the larger marine particles), although Heintzenberg et al. (2000) performed filtering on their input data to minimise the likelihood of this. Additionally, Quant et al. (1992) report that, for fine particles, aerosol collectors of the types used in some of these studies have collection efficiencies close to $100 \%$. Clarke and Kapustin (2002) noted that the detection limit for particle counters (of the type used for many of these field campaigns) was between $5-7.5 \mathrm{~nm}$ (radius) on the lower end, and 1-1.5 $\mu \mathrm{m}$ on the upper end. The 3 -standard-deviation lower limit of the marine aerosol micro- physical model used in this study is approximately $16 \mathrm{~nm}$. It is therefore likely that some of the smallest (the small end of the Aikten mode) optically-inactive particles counted may not be captured by this maritime model, meaning that the relative overestimate of the MAN-derived data estimated using a characteristic height of $1.5 \mathrm{~km}$ is larger than it appears. The extent of this is difficult to quantify and will depend on what proportion of the particles are near this lower detection limit.

Earlier reviews of field campaign data by Podzimek (1980) and Fitzgerald (1991), and the more recent review of Clarke and Kapustin (2010), suggested typical concentrations in the range of several hundred $\mathrm{cm}^{-3}$ in open oceans but several thousand $\mathrm{cm}^{-3}$ in continentally-influenced air masses. Figure 2 indicates these could still be present in the data, as many of the "maritime" subset are still in continental outflow zones, and the remoter points tend to have lower number concentrations. On separate cruises through the Eastern Atlantic, Koponen et al. (2002) and Williams et al. (2007) reported similar high aerosol number concentrations along the coast of Europe and Northern Africa, but generally less than $1000 \mathrm{~cm}^{-3}$ in marine air masses in the Southern Atlantic at mid- and high latitudes. These results are also similar to recent CTM simulations, although such models are sensitive to e.g. emission and nucleation schemes (Spracklen et al., 2010).

The main conclusion from this exercise is therefore to illustrate the difficulties inherent in inferring near-surface quantities from columnar ones. Ideally, simultaneous measurements of columnar AOD, vertical profiling, and surface particle counters would be necessary to close the loop. This difficulty is also present when, for example, trying to estimate ground-level particulate matter concentrations from satellite measurements of AOD for air quality assessment (e.g., Hoff and Christopher, 2009, and references therein).

\section{Conclusions}

The remote sensing of spectral AOD from space is not a solved problem. Ground-based measurements by techniques such as sun photometry are able to make more direct inferences about AOD, but with poorer spatial coverage. Remote sensing of aerosol number, volume, and mass would provide useful and important information about the Earth system, but is more complicated than retrieval of AOD, as it is more sensitive to assumptions relating to aerosol composition.

Using a microphysical model derived from AERONET inversions as a constraint, this study has attempted to determine columnar aerosol number and volume from shipborne measurements of spectral AOD of fairly low uncertainty $(\sim 0.015)$ for cases where this microphysical model can be reasonably assumed to be appropriate (unpolluted maritime aerosol). Even with these constraints, the estimated uncertainty on the derived quantities can be several tens of percent, with similar contributions from the uncertainties on 
AOD and the uncertainties from microphysical model parameter assumptions. This precludes use of the technique with less accurate AOD data, or when there is no prior knowledge of the aerosol microphysical properties. Despite these uncertainties, the estimated concentrations are physically sensible. It is suggested that, in conditions where a microphysical model for the dominant aerosol type can be prescribed with some confidence, accurate and precise spectral AOD measurements, such as from sun photometers deployed by the AERONET and MAN programs, could be used to estimate aerosol number or volume. However, the results reinforce the point that if the aerosol microphysical properties are not well-known, uncertainties on the derived aerosol size distribution become significantly larger, indicating that naïve fitting of spectral AOD without auxiliary information is unwise (as presented by González Jorge and Ogren, 1996).

Potential applications of this method include an additional tool for comparison with CTM aerosol fields, and examining the fine/coarse partitions retrieved or assumed in satellite AOD retrieval algorithms. Currently, AERONET size distribution inversions are sparse at some locations due to the requirement for clear skies and homogeneity over a period of one hour while almucantar scans necessary for the inversion algorithm are collected, plus a low Sun angle for high air mass factor (Dubovik and King, 2000). Although probably less accurate than these full inversions, estimates based on spectral AOD with the constraint of a microphysical model would expand the potential data volume for comparison. In estimating volume/number from spectral AOD, this is complementary to the AERONET spectral deconvolution algorithm product (O'Neill et al., 2003), which uses a more generalised set of microphysical assumptions to estimate fine and coarse contributions to midvisible AOD (but not explicitly number or volume).

An attempt was made to convert MAN-derived columnar number concentrations into surface number concentrations, which were compared to typical values from in situ datasets and AERONET estimates. From around $20^{\circ} \mathrm{S}$ and poleward, similar values were obtained $\left(\sim 300-600 \mathrm{~cm}^{-3}\right)$. However, in the tropics and Northern Hemisphere, the MAN-derived data tended to produce higher values than the in situ measurements. This poorer agreement is expected to be due to a combination of reasons including spatio-temporal variability of aerosol loading, uncertainties in aerosol microphysical properties, and, in particular, uncertainties in vertical profile shape. These quantities are highly variable and not wellconstrained at present.

Columnar aerosol number and AOD at $550 \mathrm{~nm}$ were also compared with the current Collection 5.1 product from both MODIS sensors, and results using the forthcoming Collection 6 algorithm. Consistent with previous studies, MODIS was found to overestimate AOD as compared to the MAN data, with this overestimate being larger for MODIS Terra. The number to volume ratios and per-particle extinction of the different aerosol modes used in the MODIS retrieval over ocean can lead to significant differences in derived number concentration. It was found that Terra tended to estimate lower aerosol number than MAN, and Aqua higher, linked to differences between the sensors in the aerosol fine modes which are typically found to provide the best solution. This illustrates that the underconstrained nature of the satellite retrieval problem from current sensors is more acute for number/volume concentration than for AOD, consistent with other studies (e.g. Mishchenko et al., 1997a, Hasekamp and Landgraf, 2005). The MODIS "average solution" dataset agreed more closely with the MAN data than the "best solution", likely because some of the uncertainty associated with retrieval noise and microphysical model assumptions is averaged out. The results suggest that, at least for cases of pure maritime aerosol, quality assurance flags of 1,2, and 3 are all of similar quality, and the "average solution" dataset is better than the "best solution" dataset. Collection 6 showed closer agreement with MAN AOD than Collection 5.1, indicating the algorithm improvements will provide an improved retrieval of AOD in clean maritime conditions in Collection 6, but otherwise conclusions drawn were similar. However, due to significant uncertainties in the MAN-derived estimates, such a comparison cannot be considered a direct validation of the MODIS aerosol number concentrations.

Acknowledgements. This work was supported by a grant from the NASA MEaSUREs program, managed by M. Maiden, and the EOS program, managed by $\mathrm{H}$. Maring. The authors would like to acknowledge $\mathrm{H}$. Maring for his support of the AERONET program. The authors are grateful to the AERONET, MAN, GAW, and field campaign PIs for the creation and stewardship of the ground-based data records used, and the Norwegian Institute for Air Research for hosting the GAW data. L. A. Remer is thanked for useful discussions concerning the MODIS aerosol product. MODIS data were obtained from the NASA LAADS. J. Ogren is thanked for useful comments about the GAW data. Finally, we would like to acknowledge the constructive comments of three anonymous reviewers, which we feel we have resulted in a strengthened study.

Edited by: O. Dubovik

\section{References}

Bates, T. S., Coffman, D. J., Covert, D. S., and Quinn, P. K.: Regional marine boundary layer aerosol size distributions in the Indian, Atlantic, and Pacific Oceans: a comparison of INDOEX measurements with ACE-1, ACE-2, and Aerosols99, J. Geophys. Res., 107, 8026, doi:10.1029/2001JD001174, 2002.

Blanchard, D. C. and Woodcock, A. H.: The production, concentration, and vertical distribution of the sea-salt aerosol, in: Annals of the New York Academy of Sciences, Vol. 338, Aerosols: Anthropogenic and Natural, Sources and Transport, Wiley, New York, USA, doi:10.1111/j.1749-6632.1980.tb17130.x, 1980.

Campbell, J. R., Hlavka, D. L., Welton, E. J., Flynn, C. J., Turner, D. D., Spinhirne, J. . D., Scott, V. S., and Hawng, I. H.: Full-time, eye-safe cloud and aerosol lidar observation at 
atmospheric radiation measurement program sites: instrument and data processing, J. Atmos. Ocean. Tech., 19, 431-442, doi:10.1175/1520-0426(2002)019<0431:FTESCA > 2.0.CO;2, 2002.

Carrico, C. M. and Kus, P. and Rood, M. J. and Quinn, P. K. and Bates, T. S.: Mixtures of pollution, dust, sea salt, and volcanic aerosol during ACE-Asia: Radiative properties as a function of relative humidity, J. Geophys. Res., 108(D23), 8650, doi:10.1029/2003JD003405, 2003.

Chamaillard, K., Jennings, S. G., Kleefeld, C., Ceburnis, D., and Yoon, Y. J.: Light backscattering and scattering by nonspherical sea-salt aerosols, J. Quant. Spectrosc. Ra., 79-80, 577-597, doi:10.1016/S0022-4073(02)00309-6, 2003.

Chew, B. N., Campbell, J. R., Reid, J. S., Giles, D. M., Welton, E. J., Salinas, S. V., and Liew, S. C.: Tropical cirrus cloud contamination in sun photometer data, Atmos. Environ., 45, 6724-6731, doi:10.1016/j.atmosenv.2011.08.017, 2011.

Clarke, A. D. and Kapustin, V. N.: A Pacific aerosol survey. Part I: A decade of data on particle production, transport, evolution, and mixing in the troposphere, J. Atmos. Sci., 59, 363-382, doi:10.1175/1520-0469(2002)059<0363:APASPI>2.0.CO;2, 2002.

Clarke, A. and Kapustin, V.: Hemispheric Aerosol Vertical Profiles: Anthropogenic Impacts on Optical Depth and Cloud Nuclei, Science, 329, 5998, 1488-1492, doi:10.1126/science.1188838, 2010.

Clarke, A. D., Uehara, T., and Porter, J. N.: Atmospheric nuclei and related aerosol fields over the Atlantic: clean subsiding air and continental pollution during ASTEX, J. Geophys. Res., 102, 25281-25292, doi:10.1029/97JD01555, 1997.

Clarke, A. D., Collins, W. G., Rasch, P. J., Kapustin, V. N., Moore, K., Howell, S., and Fuelberg, H. E.: Dust and pollution transport on global scales: aerosol measurements and model predictions, J. Geophys. Res., 106, 32555-32569, doi:10.1029/2000JD900842, 2001.

Dubovik, O. and King, M. D.: A flexible inversion algorithm for retrieval of aerosol optical properties from Sun and sky radiance measurements, J. Geophys. Res., 105, 20673-20696, doi:10.1029/2000JD900282, 2000.

Dubovik, O., Holben, B., Eck, T. F., Smirnov, A., Kaufman, Y., King, M., Tanré, D., and Slutsker, I.: Variability and optical properties of key aerosol types observed in worldwide locations, J. Atmos. Sci., 59, 590-608, doi:10.1175/15200469(2002)059<0590:VOAAOP > 2.0.CO;2, 2002.

Dusek, U., Covert, D. S., Widensohler, A., Neusüss, A., and Weise, D.: Aerosol number to volume ratios in Southwest Portugal during ACE-2, Tellus B, 56, 477-491, doi:10.1111/j.16000889.2004.00119.x, 2004.

Eck, T. F., Holben, B. N., Reid, J. S., Dubovik, O., Smirnov, A., O'Neill, N. T., Slutsker, I., and Kinne, S.: Wavelength dependence of the optical depth of biomass burning, urban, and desert dust aerosols, J. Geophys. Res., 104, 31333-31349, 1999.

Fitzgerald, J. W.: Model of the aerosol extinction profile in a wellmixed marine boundary layer, Appl. Optics, 28, 3534-3538, doi:10.1364/AO.28.003534, 1989.

Fitzgerald, J. W.: Marine aerosols: a review, Atmos. Environ., 25, 533-545, doi:10.1016/0960-1686(91)90050-H, 1991.

Gassó, S. and Hegg, D. A.: On the retrieval of columnar aerosol mass and CCN concentration by MODIS, J. Geophys. Res., 108,
4010, doi:10.1029/2002JD002382, 2003.

Gassó, S., Hegg, D. A., Covert, D. S., Collins, D., Noone, K. J., Öström, E., Schmid, B., Russell, P. B., Livingston, J. M., Durkee, P. A., and Jonsson, H.: Influence of humidity on the aerosol scattering coefficient and its effect on the upwelling radiance during ACE-2, Tellus B, 52, 546-567, doi:10.1034/j.16000889.2000.00055.x, 2000.

Hänel, G.: The Properties of Atmospheric Aerosol Particles as Functions of the Relative Humidity at Thermodynamic Equilibrium with the Surrounding Moist Air, Adv. Geophys., 19, 73188, doi:10.1016/S0065-2687(08)60142-9, 1976.

Hasekamp, O. P. and Landgraf, J.: Retrieval of aerosol properties over the ocean from multispectral single-viewing-angle measurements of intensity and polarization: Retrieval approach, information content, and sensitivity study, J. Geophys. Res., 110, D20207, doi:10.1029/2005JD006212, 2005.

Hegg, D. A. and Jonsson, H.: Aerosol number-to-volume relationship and relative humidity in the eastern Atlantic, J. Geophys. Res., 105, 1987-1995, doi:10.1029/1999JD901037, 2000.

Hegg, D. A. and Kaufman, Y. J.: Measurements of the relationship between submicron aerosol number and volume concentration, J. Geophys. Res., 103, 5671-5678, doi:10.1029/97JD03652, 1998.

Hegg, D. A., Covert, D. S., Rood, M. J., and Hobbs, P. V.: Measurements of aerosol optical properties in marine air, J. Geophys. Res., 101, 12893-12903, doi:10.1029/96JD00751, 1996.

Heintzenberg, J., Covert, D. C., and van Dingenen, R.: Size distribution and chemical composition of marine aerosols: a compilation and review, Tellus B, 52, 1104-1122, doi:10.1034/j.16000889.2000.00136.x, 2000.

Higurashi, A., Nakajima, T., Holben, B. N., Smirnov, A., Frouin, R., and Chatenet, B.: A Study of Global Aerosol Optical Climatology with Two-Channel AVHRR Remote Sensing, J. Clim., 13, 2011-2027, doi:10.1175/15200442(2000)013<2011:ASOGAO>2.0.CO;2, 2000.

Hoff, R. and Christopher, S.: Remote sensing of particulate pollution from space: have we reached the promised land?, J. Air Waste Manage., 59, 645-675, doi:10.3155/1047-3289.59.6.645, 2009.

Holben, B. N., Eck, T. F., Slutsker, I., Tanré, D., Buis, J. P., Setzer, A., Vermote, E., Reagan, J. A., Kaufman, Y. J., Nakajima, T., Lavenu, F., Jankowiak, I., and Smirnov, A.: AERONET: a federated instrument network and data archive for aerosol characterization, Remote Sens. Environ., 66, 1-16, doi:10.1016/S00344257(98)00031-5, 1998.

Hsu, N. C., Herman, J. R., Torres, O., Holben, B. N., Tanré, D., Eck, T. F., Smirnov, A., Chatenet, B., and Lavenu, F.: Comparisons of the TOMS aerosol index with Sun-photometer aerosol optical thickness: results and applications, J. Geophys. Res., 104, 6269-6279, doi:10.1029/1998JD200086, 1999.

González Jorge, H. and Ogren, J. A.: Sensitivity of retrieved aerosol properties to assumptions in the inversion of spectral optical depths, J. Atmos. Sci., 53, 3669-3883, 1996.

Jefferson, A.: Empirical estimates of $\mathrm{CCN}$ from aerosol optical properties at four remote sites, Atmos. Chem. Phys., 10, 68556861, doi:10.5194/acp-10-6855-2010, 2010.

Kahn, R. A., Nelson, D. L., Garay, M. J., Levy, R. C., Bull, M. A., Diner, D. J., Martonchik, J. V., Paradise, S. R., Hansen, E. G., and Remer, L. A.: MISR aerosol product attributes and statistical 
comparisons with MODIS, IEEE T. Geosci. Remote, 47, 40954114, doi:10.1109/TGRS.2009.2023115, 2009.

Kahn, R. A., Gaitley, B. J., Garay, M. J., Diner, D. J., Eck, T. F., Smirnov, A., and Holben, B. N.: Multiangle imaging spectroradiometer global aerosol product assessment by comparison with the Aerosol Robotic Network, J. Geophys. Res., 115, D23209, doi:10.1029/2010JD014601, 2010.

Kahn, R. A., Garay, M. J., Nelson, D. L., Levy, R. C., Bull, M. A., Diner, D. J., Martonchik, J. V., Hansen, E. G., Remer, L. A., and Tanré, D.: Response to "Toward unified satellite climatology of aerosol properties: 3. MODIS versus MISR versus AERONET”, J. Quant. Spectrosc. Ra., 112, 901-909, doi:10.1016/j.jqsrt.2010.11.001, 2011.

Kaskaoutis, D. G., Kharol, S. K., Sifakis, N., Nastos, P. T., Sharma, A. R., Badarinath, K. V. S., and Kambezidis, H. D.: Satellite monitoring of the biomass-burning aerosols during the wildfires of August 2007 in Greece: climate implications, Atmos. Environ., 45, 716-726, doi:10.1016/j.atmosenv.2010.09.043, 2011.

Kaufman, Y. J., Smirnov, A., Holben, B. N., and Dubovik, O.: Baseline maritime aerosol: methodology to derive the optical thickness and scattering properties, Geophys. Res. Lett., 28, 32513254, doi:10.1029/2001GL013312, 2001.

Kaufman, Y. J., Koren, I., Remer, L. A., Tanré, D., Ginous, P., and Fan, S.: Dust transport and deposition observed from the TerraModerate Resolution Imaging Spectroradiometer MODIS spacecraft over the Atlantic Ocean, J. Geophys. Res., 110, D10S12, doi:10.1088/1748-9326/1/1/014005, 2005.

Kinne, S., Schulz, M., Textor, C., Guibert, S., Balkanski, Y., Bauer, S. E., Berntsen, T., Berglen, T. F., Boucher, O., Chin, M., Collins, W., Dentener, F., Diehl, T., Easter, R., Feichter, J., Fillmore, D., Ghan, S., Ginoux, P., Gong, S., Grini, A., Hendricks, J., Herzog, M., Horowitz, L., Isaksen, I., Iversen, T., Kirkevåg, A., Kloster, S., Koch, D., Kristjansson, J. E., Krol, M., Lauer, A., Lamarque, J. F., Lesins, G., Liu, X., Lohmann, U., Montanaro, V., Myhre, G., Penner, J., Pitari, G., Reddy, S., Seland, O., Stier, P., Takemura, T., and Tie, X.: An AeroCom initial assessment - optical properties in aerosol component modules of global models, Atmos. Chem. Phys., 6, 1815-1834, doi:10.5194/acp-6-1815-2006, 2006.

Kleidman, R. G., Smirnov, A., Levy, R. C., Mattoo, S., and Tanré, D.: Evaluation and wind speed dependence of MODIS aerosol retrievals over open ocean, IEEE T. Geosci. Remote, 50, 429-435, doi:10.1109/TGRS.2011.2162073, 2012.

Knobelspiesse, K. D., Pietras, C., and Fargion, G. S.: Sun-pointingerror correction for sea deployment of the MICROTOPS II handheld sun photometer, J. Atmos. Ocean. Technol., 20, 767-771, 2003.

Knobelspiesse, K. D., Pietras, C., Fargion, G. S., Wang, M., Frouin, R., Miller, M. A., Subramaniam, A., and Balch, W. M.: Maritime aerosol optical thickness measured by handheld Sun photometers, Remote Sens. Environ., 93, 87-106, doi:10.1016/j.rse.2004.06.018, 2004.

Koffi, B., Schulz, M., Bréon, F.-M., Griesfeller, J., Winker, D., Balkanski, Y., Bauer, S., Berntsen, T., Chin, M., Collins, W. D., Dentener, F., Diehl, T., Easter, R., Ghan, S., Ginoux, P., Gong, S., Horowitz, L. W., Iversen, T., Kirkevåg, A., Koch, D., Krol, M., Myhre, G., Stier, P., and Takemura, T.: Application of the CALIOP layer product to evaluate the vertical distribution of aerosols estimated by global models, J. Geophys. Res., 117, D10201, doi:10.1029/2011JD016858, 2012.

Koponen, I. K., Virkkula, A., Hillamo, R., Kerminen, V.-M., and Kulmala, M.: Number size distributions and concentrations of marine aerosols: observations during a cruise between the English Channel and the coast of Antarctica, J. Geophys. Res., 107, 4753, doi:10.1029/2002JD002533, 2002.

Kristament, I. S., Liley, J. B., and Harbey, M. J.: Aerosol variability in the vertical in the Southwest Pacific, J. Geophys. Res., 98, 7129-7139, doi:10.1029/92JD02623, 1993.

Krüger, O. and Graß1, H.: Southern Ocean phytoplankton increases cloud albedo and reduces precipitation, Geophys. Res. Lett., 38, L08809, doi:10.1029/2011GL047116, 2011.

Li, R., Min, Q.-L., and Harrison, L. C.: A case study: The indirect aerosol effects of mineral dust on warm clouds, J. Atmos. Sci., 67, 805-816, doi:10.1175/2009JAS3235.1, 2010.

Livingston, J. M., Lapustin, V. N., Schmid, B., Russell, P. B., Quinn, P. K., Bates, T. S., Durkee, P. A., Smith, P. J., Freudenthaler, V., Wiegner, M., Covert, D. S., Gassó, S., Hegg, D., Collins, D. R., Flagan, R. C., Seinfeld, J. H. Vitale, V., and Tomasi, C.: Shipboard sunphotometer measurements of aerosol optical depth spectra and columnar water vapor during ACE2 , and comparison with selected land, ship, aircraft, and satellite measurements, Tellus B, 52, 594-619, doi:10.1034/j.16000889.2000.00045.x, 2000.

McClatchey, R. A., Fenn, R. W., Selby, J. E. A., Volz, F. E., and Garing, J. S.: Optical properties of the Atmosphere (3rd edn.), Tech. rep., report number AFCRL-TR-71-0279, environmental research paper 354, Air Force Cambridge Research Laboratories, Bedford, Mass., USA, 1972.

Michalsky, J. J., Schlemmer, J. A., Berkheiser, W. E., Berndt, J. L., Harrison, L. C., Laulainen, N. S., Larson, N. R., and Barnard, J. C.: Multiyear measurements of aerosol optical depth in the Atmospheric Radiation Measurement and Quantitative Links programs, J. Geophys. Res., 106, 12099-12107, doi:10.1029/2001JD900096, 2001.

Mishchenko, M. I., Travis, L. D., Rossow, W. B., Cairns, B., Carlson, B. E. and Han, Q.: Retrieving CCN column density from single-channel measurements of reflected sunlight over the ocean: A sensitivity study, Geophys. Res. Lett., 24, 2655-2658, doi:10.1029/97GL02783, 1997a.

Mishchenko, M. I., Travis, L. D., Kahn, R. A., and West, R. A.: Modeling phase functions for dustlike tropospheric aerosols using a shape mixture of randomly oriented polydisperse spheroids J. Geophys. Res., 102, 16831-16847, doi:10.1029/96JD02110, 1997b.

Mishchenko, M., Geogdzhayez, I. V., Cairns, B., Carlson, B. E., Chowdhary, J., Lacis, A. A., Liu, L., Rossow, W. B., and Travis, L. D.: Past, present, and future of global aerosol climatologies derived from satellite observations: a perspective, J. Quant. Spectrosc. Ra., 106, 325-347, doi:10.1016/j.jqsrt.2007.01.007, 2007.

Mishchenko, M. I., Liu, L., Travis, L. D., Lacis, A. A., and Cairns, B.: Toward unified satellite climatology of aerosol properties: 3. MODIS versus MISR versus AERONET, J. Quant. Spectrosc. Ra., 111, 540-552, 2010.

O'Neill, N. T., Ignatov, A., Holben, B. N., and Eck, T. F.: The lognormal distribution as a reference for reporting aerosol optical depth statistics; empirical tests using multi-year, multi-site 
AERONET sunphotometer data, Geophys. Res. Lett., 27, 33333336, doi:10.1029/2000GL011581, 2000.

O’Neill, N. T., Eck, T. F., Smirnov, A., Holben, B. N., and Thulasiraman, S.: Spectral discrimination of coarse and fine mode optical depth, J. Geophys. Res., 108, 4559-4573, doi:10.1029/2002JD002975, 2003.

Patterson, E. M., Kiang, C. S., Delany, A. C., Wartburg, A. F., Leslie, A. C. D., and Huebert, B. J.: Global measurements of aerosols in remote continental and marine regions: concentrations, size distributions, and optical properties, J. Geophys. Res., 85, 7361-7376, doi:10.1029/JC085iC12p07361, 1980.

Podzimek, J.: Advances in marine aerosol research, J. Rech. Atmos., 14, 35-61, 1980.

Porter, J. N., Miller, M., Pietras, C., and Motell, C.: Ship-based sun photometer measurements using Microtops sun photometers, J. Atmos. Ocean. Techn., 18, 765-774, doi:10.1175/15200426(2001)018<0765:SBSPMU>2.0.CO;2, 2001.

Quaas, J., Boucher, O., Bellouin, N., and Kinne, S.: Satellite-based estimate of the direct and indirect aerosol climate forcing, J. Geophys. Res., 113, D05204, doi:10.1029/2007JD008962, 2008.

Quant, F. R., Caldow, E., Sem, G. J., and Addison, T. J.: Performance of condensation particle counters with three continuousflow designs, J. Aerosol. Sci., 23, 405-408, 1992.

Quinby-Hunt, M. S., Erskine, L. L., and Hunt, A. J.: Polarized light scattering by aerosols in the marine atmospheric boundary layer, Appl. Optics, 36, 5168-5185, doi:10.1364/AO.36.005168, 1997.

Reid, J. S., Brooks, B., Crahan, K. K., Hegg, D. A., Eck, T. F., O'Neill, N., de Leeuw, G., Reid, E. A., and Anderson, K. D.: Reconciliation of coarse mode sea-salt aerosol particle size measurements and parameterizations at a subtropical ocean receptor site, J. Geophys. Res., 111, D02202, doi:10.1029/2005JD006200, 2006.

Remer, L. A., Kaufman, Y. J., Tanré, D., Mattoo, S., Chu, D. A., Martins, J. V., Li, R.-R., Ichoku, C., Levy, R. C., Kleidman, R. G., Eck, T. F., Vermote, E., and Holben, B. N.: The MODIS aerosol algorithm, products, and validation, J. Atmos. Sci., 62, 947-973, 2005.

Remer, L. A., Kleidman, R. G., Levy, R. C., Kaufman, Y. J., Tanré, D., Mattoo, S., Martins, J. V., Ichoku, C., Koren, I., Yu, H., and Holben, B. N.: Global aerosol climatology from the MODIS satellite sensors, J. Geophys. Res., 113, D14S07, doi:10.1029/2007JD009661, 2008.

Remer, L. A., Tanré, D., and Kaufman, Y. J.: Algorithm for remote sensing of tropospheric aerosol from MODIS: collection 5, Tech. rep., ATBD-MOD-02, product ID MOD04/MYD04, available at: http://modis.gsfc.nasa.gov/data/atbd/, last access: May 2012, NASA Goddard Space Flight Center, 2009.

Russell, P. B., Hobbs, P. V., and Stowe, L. L.: Aerosol properties and radiative effects in the United States East Coast haze plume: an overview of the Tropospheric Aerosol Radiative Forcing Observational Experiment (TARFOX), J. Geophys. Res., 104, 22132222, doi:10.1029/1998JD200028, 1999a.

Russell, P. B., Livingstone, J. M., Hignett, P., Kinne, S., Wong, J., Chien, A., Bergstrom, R., Durkee, P., and Hobbs, P. V.: Aerosolinduced radiative flux changes off the United States Mid-Atlantic coast: comparison of values calculated from sunphotometer and in situ data with those measured by airborne pyranometer, J. Geophys. Res., 104, 2289-2307, doi:10.1029/1998JD200025, 1999b.
Sayer, A. M., Thomas, G. E., and Grainger, R. G.: A sea surface reflectance model for (A)ATSR, and application to aerosol retrievals, Atmos. Meas. Tech., 3, 813-838, doi:10.5194/amt-3813-2010, 2010.

Sayer, A. M., Hsu, N. C., Bettenhausen, C., Ahmad, Z., Holben, B. N., Smirnov, A., Thomas, G. E., and Zhang, J.: SeaWiFS Ocean Aerosol Retrieval (SOAR): algorithm, validation, and comparison with other datasets, J. Geophys. Res., 117, D03206, doi:10.1029/2011JD016599, 2012a.

Sayer, A. M., Smirnov, A., Hsu, N. C., and Holben, B. N.: A pure marine aerosol model, for use in remote sensing applications, J. Geophys. Res., 117, D05213, doi:10.1029/2011JD016689, 2012b.

Schmid, B., Livingston, J. M., Russell, P. B., Durkee, P. A., Jonsson, H. H., Collins, D. R., Flagan, R. C., Seinfeld, J. H. Hegg, D. A., Gassó, S., Öström, E., Noone, K. J., Welton, E., Voss, K. J., Gordon, H. R., Formenti, P., and Andreae, M. O.: Clear-sky closure studies of lower tropospheric aerosol and water vapor during ACE-2 using airborne sunphotometer, airborne in-situ, space-borne, and groundbased measurements, Tellus B, 52, 568-593, doi:10.1034/j.16000889.2000.00009.x, 2000.

Sebacher, D. I., Harriss, R. C., Cofer III, W. R., and Browell, E. V.: Influence of meteorological conditions on aerosol vertical distribution and composition off the Northeast American coastline, Atmos. Environ., 19, 423-428, doi:10.1016/00046981(85)90164-7, 1967.

Sharma, N. C. P., Barnes, J. E., Kaplan, T. B., and Clarke, A. D.: Coastal Aerosol Profiling with a Camera Lidar and Nephelometer, J. Atmos. Oceanic Technol., 28, 418-425, doi:10.1175/2010JTECHA1482.1, 2011.

Shi, Y., Zhang, J., Reid, J. S., Holben, B., Hyer, E. J., and Curtis, C.: An analysis of the collection 5 MODIS over-ocean aerosol optical depth product for its implication in aerosol assimilation, Atmos. Chem. Phys., 11, 557-565, doi:10.5194/acp-11-557-2011, 2011.

Smirnov, A., Holben, B. N., Dubovik, O., Eck, T. F., and Slutsker, I.: Optical properties of atmospheric aerosol in maritime environments, Opt. Pura. Appl., 37, 3453-3490, 2004.

Smirnov, A., Holben, B. N., Slutsker, I., Giles, D. M., McClain, C. R., Eck, T. F., Sakerin, S. M., Macke, A., Croot, P., Zibordi, G., Quinn, P. K., Sciare, J., Kinne, S., Harvey, M., Smyth, T. J., Piketh, S., Zielinski, T., Proshuninsky, A., Goes, J. I., Nelson, N. B., Larouche, P., Radionov, V. F., Goloub, P., Moorthy, K. K., Matarresse, R., Robertson, E. J., and Jourdin, F.: Maritime Aerosol Network as a component of Aerosol Robotic Network, J. Geophys. Res., 112, D06204, doi:10.1029/2008JD011257, 2009.

Smirnov, A., Holben, B. N., Giles, D. M., Slutsker, I., O’Neill, N. T., Eck, T. F., Macke, A., Croot, P., Courcoux, Y., Sakerin, S. M., Smyth, T. J., Zielinski, T., Zibordi, G., Goes, J. I., Harvey, M. J., Quinn, P. K., Nelson, N. B., Radionov, V. F., Duarte, C. M., Losno, R., Sciare, J., Voss, K. J., Kinne, S., Nalli, N. R., Joseph, E., Krishna Moorthy, K., Covert, D. S., Gulev, S. K., Milinevsky, G., Larouche, P., Belanger, S., Horne, E., Chin, M., Remer, L. A., Kahn, R. A., Reid, J. S., Schulz, M., Heald, C. L., Zhang, J., Lapina, K., Kleidman, R. G., Griesfeller, J., Gaitley, B. J., Tan, Q., and Diehl, T. L.: Maritime aerosol network as a component of AERONET - first results and comparison 
with global aerosol models and satellite retrievals, Atmos. Meas. Tech., 4, 583-597, doi:10.5194/amt-4-583-2011, 2011.

Smirnov, A., Sayer, A. M., Holben, B. N., Hsu, N. C., Sakerin, S. M., Macke, A., Nelson, N. B., Courcoux, Y., Smyth, T. J., Croot, P., Quinn, P. K., Sciare, J., Gulev, S. K., Piketh, S., Losno, R., Kinne, S., and Radionov, V. F.: Effect of wind speed on aerosol optical depth over remote oceans, based on data from the Maritime Aerosol Network, Atmos. Meas. Tech., 5, 377-388, doi:10.5194/amt-5-377-2012, 2012.

Spracklen, D. V., Carslaw, K. S., Merikanto, J., Mann, G. W., Reddington, C. L., Pickering, S., Ogren, J. A., Andrews, E., Baltensperger, U., Weingartner, E., Boy, M., Kulmala, M., Laakso, L., Lihavainen, H., Kivekäs, N., Komppula, M., Mihalopoulos, N., Kouvarakis, G., Jennings, S. G., O’Dowd, C., Birmili, W., Wiedensohler, A., Weller, R., Gras, J., Laj, P., Sellegri, K., Bonn, B., Krejci, R., Laaksonen, A., Hamed, A., Minikin, A., Harrison, R. M., Talbot, R., and Sun, J.: Explaining global surface aerosol number concentrations in terms of primary emissions and particle formation, Atmos. Chem. Phys., 10, 4775-4793, doi:10.5194/acp-10-4775-2010, 2010.

Stowe, L. L., Ignatov, A. M., and Singh, R. R: Development, validation, and potential enhancements to the second-generation operational aerosol product at the National Environmental Satellite, Data, and Information Service of the National Oceanic and Atmospheric Administration J. Geophys. Res., 102, 16923-16993, doi:10.1029/96JD02132, 1997.

Sturm, B.: The atmospheric correction of remotely sensed data and the quantitative determination of suspended matter in marine water surface layers, in: Remote Sensing in Meteorology, Oceanography and Hydrology, edited by: Cracknell, A. P., Ellis Horwood, Chichester, UK, 1980.

Tang, I. N.: Chemical and size effects of hygroscopic aerosols on light scattering coefficients, J. Geophys. Res., 101, 1924519250, doi:10.1029/96JD03003, 1996.

Tanré, D., Kaufman, Y. J., Herman, M., and Mattoo, S.: Remote sensing of aerosol properties over oceans using the MODIS/EOS spectral radiances, J. Geophys. Res., 102, 1697116988, doi:10.1029/96JD03437, 1997.

Textor, C., Schulz, M., Guibert, S., Kinne, S., Balkanski, Y., Bauer, S., Berntsen, T., Berglen, T., Boucher, O., Chin, M., Dentener, F., Diehl, T., Easter, R., Feichter, H., Fillmore, D., Ghan, S., Ginoux, P., Gong, S., Grini, A., Hendricks, J., Horowitz, L., Huang, P., Isaksen, I., Iversen, I., Kloster, S., Koch, D., Kirkevåg, A., Kristjansson, J. E., Krol, M., Lauer, A., Lamarque, J. F., Liu, X., Montanaro, V., Myhre, G., Penner, J., Pitari, G., Reddy, S., Seland, Ø., Stier, P., Takemura, T., and Tie, X.: Analysis and quantification of the diversities of aerosol life cycles within AeroCom, Atmos. Chem. Phys., 6, 1777-1813, doi:10.5194/acp-6-1777-2006, 2006.

Thomas, G. E., Poulsen, C. A., Sayer, A. M., Marsh, S. H., Dean, S. M., Carboni, E., Siddans, R., and Grainger, R. G.: Oxford-RAL Aerosol and Cloud (ORAC): aerosol retrievals from satellite radiometers, in: Aerosol Remote Sensing over Land, edited by: Kokhanvosky, A. A. and de Leeuw, G., Springer, Berlin, Germany, 2009.
Torres, O., Bhartia, P. K., Herman, J. R., Sinyuk, A., Ginoux, P., and Holben, B.: A long-term record of aerosol optical depth from TOMS observations and comparison to AERONET measurements, J. Atmos. Sci., 59, 398-413, doi:10.1175/15200469(2002)059<0398:ALTROA>2.0.CO;2, 2002.

van Dingenen, R., Raes, F., Putaud, J.-P., Virkkula, A., and Mangoni, M.: Processes determining the relationship between aerosol number and non-sea-salt sulfate mass concentrations in the clean and perturbed marine boundary layer, J. Geophys. Res., 104, 8027-8038, doi:10.1029/1998JD100059, 1999.

Voss, K. J., Welton, E. J., Quinn, P. K., Johnson, J., Thompson, A. M., and Gordon, H. R.: Lidar measurements during Aerosols99, J. Geophys. Res., 106, 20821-20831, doi:10.1029/2001JD900217, 2001.

Wagner, F. and Silva, A. M.: Some considerations about Ångström exponent distributions, Atmos. Chem. Phys., 8, 481-489, doi:10.5194/acp-8-481-2008, 2008.

Wang, W. and Rood, M. J. and Carrico, C. M. and Covert, D. S. and Quinn, P. K. and Bates, T. S.: Aerosol optical properties along the northeast coast of North America during the New England Air Quality Study-Intercontinental Transport and Chemical Transformation 2004 campaign and the influence of aerosol composition, J. Geophys. Res., 112, D10S23, doi:10.1029/2006JD007579, 2007.

Welton, E. J., Voss, K. J., Quinn, P. K., Flatau, P. J., Markowicz, K., Campbell, J. R., Spinhire, J. D., Gordon, H. R., and Johnson, J. E.: Measurements of aerosol vertical profiles and optical properties during INDOEX 1999 using micropulse lidars, J. Geophys. Res., 107, 8019, doi:10.1029/2000JD000038, 2002.

Williams, P. I., McFiggans, G., and Gallagher, M. W.: Latitudinal aerosol size distribution variation in the Eastern Atlantic Ocean measured aboard the FS-Polarstern, Atmos. Chem. Phys., 7, 2563-2573, doi:10.5194/acp-7-2563-2007, 2007.

Yershov, O. A., Smirnov, A. V., and Shifrin, K. S.: The vertical profile of aerosol optical depths of maritime atmosphere (in Russian), Leningrad, in: Atmospheric and Marine Optics, edited by: Shifrin, K. S., Leningrad, Russia, 1988.

Yu, F., Luo, G., Turco, R. P., Ogren, J. A., and Yantosca, R. M.: Decreasing particle number concentrations in a warming atmosphere and implications, Atmos. Chem. Phys., 12, 2399-2408, doi:10.5194/acp-12-2399-2012, 2012.

Yu, H., Chin, M., Winker, D. M., Omar, A. H., Liu, Z., Kittake, C., and Diehl, T.: Global view of aerosol vertical distributions from CALIPSO lidar measurements and GOCART simulations: Regional and seasonal variations, J. Geophys. Res., 115, D00H30, doi:10.1029/2009JD013364, 2010.

Zhang, J. and Reid, J. S.: MODIS aerosol product analysis for data assimilation: assessment of over-ocean level 2 aerosol optical thickness retrievals, J. Geophys. Res., 111, D22207, doi:10.1029/2005JD006898, 2006. 